\title{
Profitability of foreign and domestic banks in Central and Eastern Europe: does the mode of entry matter?*
}

\author{
Olena Havrylchyk ${ }^{* *}$, CEPII, Paris \\ Emilia Jurzyk, Department of Economics and LICOS, KU Leuven
}

January 2006

\begin{abstract}
Using data for 265 banks in the Central and Eastern European Countries for the period of 1995-2003, this paper analyses the differences in profitability between domestic and foreign banks. We show that foreign banks, especially greenfield institutions, earn higher profits than domestic banks. However, this effect is acquired, rather than inherited, since there is evidence that foreign banks tend to take over less profitable institutions. Profits of foreign banks in the CEEC also exceed profits of their parent banks, explaining the reasons for their entry. Further, we study benefits and costs of foreign ownership by analyzing determinants of profitability for domestic, takeover, and greenfield banks. Profits of foreign banks are less affected by macroeconomic conditions in their host countries. However, greenfield banks are sensitive to the situation of their parent banks. Only domestic banks enjoy higher profits in more concentrated banking markets, whereas takeover banks suffer from diseconomies of scale due to the fact that they acquired large institutions.
\end{abstract}

JEL classification: G15, G21, F36

Keywords: Foreign banks, Bank profits, Multinational banking, Transition economies

\footnotetext{
* We would like to thank Bo Becker, Hans Degryse, Iikka Korhonen, and Agnès Bénassy-Quéré, as well as participants at the OENB, ECB and CFS Conference on European Economic Integration, XIV International Tor Vergata Conference on Banking and Finance, LICOS ITD - Monetary and Information Economics seminar at the KU Leuven and seminar at the National Bank of Poland for helpful comments and suggestions. The remaining errors are the sole responsibility of the authors.

** The corresponding author Olena Havrylchyk, CEPII, 9 rue Georges Pitard, 75015, Paris, France; e-mail: olena.havrylchyk@cepii; tel: +33 0153685509
} 


\section{Introduction}

Foreign banks have played an important role in the development of banking markets in the Central and Eastern European Countries (CEEC). First of all, the capital brought by foreign investors decreased fiscal costs of banks' restructuring. Often privatization to reputable foreign owners was the only way to decrease moral hazard problems induced by previous repetitive bailouts (Tang et al., 2000). Second, foreign banks brought expertise in risk management and higher culture of corporate governance, rendering banks more efficient (Bonin et al., 2005). Third, foreign bank presence increased competition, driving domestic banks to cut costs and increase efficiency (Claessens et al., 2001). Finally, domestic banks have benefited from technological spillovers brought about by their foreign competitors. While the benefits of foreign ownership for bank efficiency in transition countries seem to be proven, the impact on banking sector stability is less clear. In our paper we address this issue by looking at the determinants of bank profitability in the CEEC.

Theoretically, profits of foreign banks can be affected by business conditions in their home countries and by health or change in strategy of their parent banks. This can have both costs and benefits for banking industries in the CEEC. The largest advantage of foreign ownership is smaller sensitivity of foreign banks to host country conditions and significantly better access to international markets. The international experience also shows that parent banks serve as lenders-of-last-resort if their subsidiaries run into troubles. For example, a Belgian bank KBC recapitalized its Polish subsidiary Kredyt Bank, and its Hungarian subsidiary $\mathrm{K} \& \mathrm{H}$, when they encountered problems. In the case of Kredyt Bank, problems stemmed from rapid loan growth that later resulted in large non-performing loans, whereas problems of K\&H were caused by fraudulent activities of its management.

At the same time, foreign banks can be influenced by poor performance or change in strategy of their parent banks. There are two main channels that are worth considering. First, foreign banks could be liquidated if their parent banks experience problems on their own and decide to close some of their subsidiaries. The recent example of the impact that the parent bank situation had on foreign banks operating in the CEEC was the withdrawal of the Dresdner Bank from Romania and the Czech Republic, which seemed to be linked to the problems of the Dresdner Bank at the headquarters. Second, managers of international banks admit that they allocate capital to the subsidiaries with the highest expected returns (de Haas \& Naaborg, 2005). Therefore, even a profitable foreign subsidiary could be closed in order to reallocate capital to even more profitable project in another country.

The impact of home country conditions on foreign banks is more ambiguous and cannot be easily predicted. Let us assume, for example, that home country experiences an economic upswing. In this situation parent banks have numerous profitable opportunities in their home countries, and can decide to allocate less capital to their subsidiaries. At the same time, high growth in the home country could make parent banks more profitable and more capable to develop their subsidiaries abroad. The situation would be inverse in case of economic slowdown in home country, when parent banks could decide either to cut their foreign operations due to low profits at home or expand abroad for new opportunities.

Taking into account the above discussion, in this paper we attempt to answer the following questions:

1. Did foreign banks acquire more or less profitable institutions in the CEEC? 
2. Are foreign and domestic banks affected in the same way by macroeconomic conditions in their host countries?

3. Are foreign banks sensitive to macroeconomic conditions in their home countries and to financial situation of their parent banks?

4. Does market concentration in host countries have the same impact on foreign and domestic banks?

5. Which effect does the stage of banking sector reform and development of financial market have on profitability?

It should be mentioned that in our study we always differentiate between foreign banks that took over existing institutions (takeover banks) and those that established new institutions (greenfield banks). This distinction is very important because there are big differences in strategies pursued by these banks. Greenfield banks traditionally service large international corporations, hence they could be more influenced by home country conditions and financial situation of their parent banks than takeover banks, which are more involved in domestic retail markets.

The present paper investigates the determinants of banks' profitability using a dataset comprising 265 banks from 10 CEEC (Bulgaria, the Czech Republic, Estonia, Hungary, Latvia, Lithuania, Poland, Romania, Slovakia, Slovenia) between 1995-2003. Since our interest lies in the profitability determinants of banks with different ownership, we estimated regressions for the whole sample and for the domestic, foreign, takeover, and greenfield banks separately. In order to get insight into the factors that affect the profitability of banks in the CEEC, we investigated the relationship between banks' return on assets and five groups of variables: a) individual banks' characteristics (bank ownership, loan growth, capitalization, and bank's share in the total banking assets); b) host country macroeconomic conditions (GDP growth, inflation rates, real money market rates, real effective exchange rate); c) indicators of financial sector development of host countries (EBRD index of banking sector reforms, stock market capitalization, credit to the private sector, crisis dummies, HerfindahlHirshman index of banking sector concentration); d) parent banks' performance indicators (NIM, ROA, capitalization); e) home country macroeconomic conditions (GDP growth, real money market rates).

In our paper we contribute to the literature in a few ways. First, in our analysis of profitability we clearly differentiate between mode of entry of foreign banks, namely banks that established greenfield institutions and those that took over existing domestic banks. Second, we assume that foreign and domestic banks can react differently to the same profitability determinants, such as domestic macroeconomic situation, market structure, and level of banking sector development. Therefore, we construct separate econometric models for domestic, greenfield and takeover banks. Finally, we focus on transition countries and test a number of hypotheses, which have been already tested for developed countries, but might have different results in the CEEC.

The paper is structured in the following way. In Section 2, we present a short review of circumstances under which foreign banks entered the CEEC. In Section 3 we summarize the existing literature on bank profitability and focus on determinants specific to foreign banks. In Section 4 we present the data and descriptive statistics for profitability of foreign and domestic banks. Sections 5 and 6 present econometric methodology and empirical results. Section 7 concludes. 


\section{Entry of foreign banks into the banking sectors of the CEEC}

The banking sectors in the CEEC are characterized by very high level of foreign presence (Table 1). In Hungary, the Czech Republic, and Estonia foreign banks control more than 80\% of the total banking capital. The largest five foreign owners in the CEEC constitute KBC Bank, Erste Bank, HVB Group, Societe Generale and Unicredito Italiano (Table 2). It is easy to notice a regional specialization of some foreign banks. Large Scandinavian banks (Swedbank and Skandinavska Enskilda) virtually monopolize banking markets of the Baltic states, and Greek banks (National Bank of Greece, Piraeus Bank, Alpha Bank, Emporiki Bank of Greece) have a foothold only in the Balkan countries. At the same time, Austrian banks (Erste Bank, HVB Group ${ }^{1}$, Raiffeisen) control large shares of banking assets in all CEEC, except for the Baltic states. There are also a few examples when CEE banks have stakes in banks of other CEEC. For example, Hungarian OTP bank acquired banks in Bulgaria and Slovakia, and Latvian Parex bank took over Lithuanian AB Industrijos Bankas. Mian (2005) reports that there are significant distance constraints for foreign banks and finds that as the geographical distance between banks and the host country increases, so do the information and agency costs. Therefore, it is not surprising to see that foreign banks enter country with more familiar culture and social customs, and whose economic, political and social environment they know best.

The entry of foreign owners into the CEEC banking markets has not always been so easy. In the beginning of 90s, only few foreign banks entered the CEEC by establishing greenfield institutions. This was motivated by two factors: lack of support for foreign bank ownership in the CEEC and low attractiveness of these countries before embarking on structural reforms. The established greenfield banks followed foreign enterprises into CEEC and focused their operations on them. At the same time they were studying local markets for opportunities. These greenfield banks grew rapidly in the CEEC, and they have also acquired large domestic banks when privatization process started.

\section{Hungary}

The first country in the CEEC to invite foreign strategic investors was Hungary. Until 1994 foreign investors were limited to minority shares in Hungarian banks. The Hungarian banking sector, however, was suffering from loose budget constraints and moral hazard problems, resulting from repeated bank recapitalizations between 1993-1994. In order to improve corporate governance of banks and decrease fiscal costs of recapitalizations the consensus was reached in 1994 to privatize banks to strategic foreign investors. The process was completed by the end of 1997 when all large banks were controlled by foreign owners. The only exception was OTP, the largest Hungarian savings bank that was privatized through the public offering on the stock exchange to institutional investors, without a single majority owner.

\section{Baltic States}

Baltic states have also been fast in inviting foreign investors, however foreign banks were able to take over strategic ownership only after the Russian crisis in 1998. Banks in this region had a high exposure to the Russian market and many banks experienced financial

\footnotetext{
${ }^{1}$ HVB Group is formally a German group, but it became the leader in CEEC banking market after the acquisition of Bank Austria Creditanstalt, an Austrian bank that had large presence in the CEEC.
} 
difficulties in the wake of the Russian crisis. For example, 10\% of Latvian banks' assets were exposed to the Russian market with more than one third of this exposure being to the Russian GKO bonds. As a result, the liquidity of banks was reduced, interbank market has dried up, and there was an outflow of non-resident deposits. Rigas Komercbanka, the country's fifth largest bank, was subject to a bank run. It held $14 \%$ of its assets in Russia, and about $20 \%$ of its capital was owned by Russian investors. The bank was declared insolvent together with a few other, smaller banks. Estonian and Lithuanian banks were less exposed to the Russian market but nevertheless their profitability was affected. The crisis led to a consolidation of the banking markets and privatization of the last state banks. As a result of this restructuring, foreign banks, which had already been present in the Baltic states, gained even a higher share of the local market.

\section{Balkan States}

Bulgaria and Romania have both been reluctant to privatize their banks to foreign strategic investors, and only the banking crises have led to rethinking of their strategies. Bulgaria experienced a banking crisis in 1996-1997, and Romania had the same experience in 19981999. The underlying reasons for both events were very similar: soft budget constraints, inadequate laws, and virtually unlimited liquidity provided by central banks. In Bulgaria soft budget constrains led to a lending boom, but by 1995 roughly $75 \%$ of all bank loans were classified as nonperforming. Faced with this situation, the Bulgarian central bank provided liquidity, which ended in currency and banking crisis. In 1997 the Bulgarian authorities finally embarked on the privatization, and major Bulgarian banks were sold to foreign strategic investors. Before the crisis in Romania, large state owned banks were giving loans to inefficient state enterprises, and were quasi-automatically refinanced by the central bank. When the central bank decided to change its policy and discontinue this practice, many large banks experienced difficulties. After costly recapitalizations, the authorities began the privatization process with the active participation of foreign investors.

\section{Poland}

Poland did not incur large fiscal costs to support its banking sector, and this might have been one of the reasons why the political opposition to foreign bank ownership was very strong. Between 1992 and 1998 conditional licensing was applied to foreign banks, meaning that a foreign bank could obtain a license only after agreeing to rehabilitate a distressed Polish bank. The privatization process started in 1993. Even though foreign investors were allowed to participate, they were entitled only to minority shares. Restrictions on foreign banks were removed in 1998 after the passing of new laws on banking, which were in line with the EU legislation. The concept of privatization changed as well and the government started to seek reputable foreign banks in order to collect large privatization revenues. The high minimum capital requirement of 5 million ECU accelerated the involvement of foreign banks since domestic banks could not raise such large amounts of money on the local market.

\section{Czech Republic}

The Czech Republic decided to restructure its banking sector through voucher privatization. The mass privatization turned out to be a failure and the Czech Republic suffered from one of the highest fiscal costs of bank restructuring (25.4\% of GDP) in the CEEC. In 1998, the government sold its stake in Investicna a Postovna Banka (IPB) to the Japanese investor firm Nomura. This was the first time when a foreign investor had the opportunity to acquire a majority interest in a large Czech Bank. As the IPB was declared insolvent in 2000, the 
benefits of foreign ownership were put under doubt. However, the privatization to foreign investors continued. The Erste Bank and Societe Generale acquired majority shares in large banks but this happened only after the Czech government protected the new owners against the remaining credit risks on loan portfolios through a ring-fencing agreement. In 2003, 85\% of Czech banking capital was controlled by foreign investors.

\section{Slovak Republic}

The banking reform started late in Slovak Republic. Due to continuous political interference into lending practices, banks accumulated a burden of non-performing loans. However, starting in 1999, reforms accelerated, major banks were recapitalized and sold to strategic foreign investors.

\section{Slovenia}

In 2003, 32.5\% of Slovenian bank capital was in hands of foreign owners, a much lower ratio than in its CEE peers. Having started from a more favorable position than the other CEEC, Sovenia chose not to privatize banks and limit the foreign competition. It should be mentioned that this strategy has proved to be correct as bank intermediation developed rapidly and no major banking crises occurred. However, the competition between Slovenian banks has remained rather weak, and this led to a change in attitudes to foreign ownership. As a result, between 2001 and 2003, foreign investors increased their ownership from 13\% to 32.5\% of bank capital.

\section{Determinants of foreign bank profits: literature overview}

First of all, it should be mentioned that the literature offers a number of definitions of profitability. In our analysis we follow the accounting definition, such as return on assets (ROA). From the bank's income statement, profits after taxes divided by total assets satisfy the following accounting identity:

$$
R O A=N I M+\frac{N I I}{T A}-\frac{O V}{T A}-\frac{L L P}{T A}-\frac{T X}{T A},
$$

where ROA is return on assets, NIM - net interest margin, NII - non-interest income, TA total assets, OV - overhead, LLP - loan loss provisions, TX - taxes.

Therefore, our definition is very broad and includes many aspects of the banking business. The literature that is presented in this section mostly focuses on analysis of determinants of ROA.

It has been noticed for a long time that foreign banks in developed countries exhibit lower profitability than their domestic competitors, whereas the opposite is true for transition economies. Demirguc-Kunt and Huizinga (2001) document lower returns on assets for foreign banks in the US, Canada, the UK, Germany, France, and in the Netherlands. De Young and Nolle (1996) analyze this phenomenon for the US market and find evidence that foreign banks sacrifice profits in exchange for larger market share. At the same time, Bonin et al. (2005) show that foreign banks in most of the transition countries enjoy higher profitability than domestic banks. However, Majnoni et al. (2003), in their study of the Hungarian banking market, underline that a majority of well-performing foreign institutions have been created as greenfield investments without inheriting problems related to inefficient branch network, 
underdeveloped IT, and low-quality clientele. Chmielewski and Krzesniak (2003) show that foreign banks in Poland underperform domestic banks in terms of return on assets.

In light of the above differences, it is important to understand the determinants of bank profits and, indeed, the bank profitability literature is very extensive. However, the majority of papers focuses on markets with low presence of foreign banks. They ignore two facts: first, that foreign banks might be affected by the same factors differently than domestic banks, and, second, that they can be also affected by additional factors, such as their home country conditions and strategy of their parent institutions. In this section, we first review the literature on determinants of bank profits for all banks, and then we focus on factors which are more relevant for foreign banks.

One of the most frequently tested hypothesis in the profitability literature is the structureconduct-performance (SCP) paradigm, which argues that higher market concentration causes less competitive bank behavior ${ }^{2}$ and leads to higher bank profitability (see Gilbert, 1984, for a survey). A similar hypothesis of relative market power (RMP) states that firms with higher market power are able to earn abnormal profits. Additionally, it is hypothesized that managers of large firms could make less effort to maximize efficiency, the so called "quiet life" effect (Berger and Hannan, 1998).

Alternative explanation of the positive relationship between high concentration and profitability is offered by Demsetz (1973). He formulates the efficient structure (ES) hypothesis, which suggests that more efficient banks, which are also more profitable, earn additional market power, leading to the increase of the industry concentration. Berger (1995) attempts to distinguish between the SCP, RMP, and the ES hypotheses and, even thought he finds that the superior X-efficiency is associated with higher profits, he does not find the proof that this leads to higher concentration of the market. At the same time his results provide support for the RMP hypothesis but run contrary to the SCP paradigm.

Apart from the market structure, bank profitability can be affected by bank's own strategy, which can be derived from the structure of its balance sheet and income statement. One of the most important factors influencing bank profits is the capital ratio. Berger (1995) proposes two hypotheses for the positive effect of capital on earnings: 1) the expected bankruptcy hypothesis states that the increased capital leads to higher earnings due to reduced interest rates on uninsured funds, especially for riskier banks, whose probability of bankruptcy decreases; 2) the signaling hypothesis assumes that managers have private information about the future cash flow and, therefore, signal about this by their capital decisions. Berger (1995) and Demirguc-Kunt and Huizinga (1999) provide empirical evidence in support of the expected bankruptcy hypothesis.

A number of other accounting ratios with respect to total assets have been controlled for in the literature and the most common ones include loans, liquid assets, investments, non-interest bearing assets, off-balance-sheet items, customer and short term funding, other funding, net interest income and overhead expenses (Demirguc-Kunt and Huizinga, 1999; Goddart et al., 2004; Kosmidou et al., 2004; Gonzalez, 2004).

\footnotetext{
2 The relationship between market concentration and competition can be more complex. Claessens and Laeven (2004) estimate degree of competition in 50 developed and developing countries and demonstrate that more concentrated banking markets face actually more competition than less concentrated markets. Similarly, the number of banks is never significantly positively related to the competition indicator. Berger et al. (2004) offer a good review of the current stance of the theoretical and empirical research on the relationship between bank concentration and competition.
} 
The macroeconomic environment has a direct effect on bank profits, hence some studies control for macroeconomic conditions. For example Demirguc-Kunt and Huizinga (1999) find a positive relationship between inflation and real interest rate on the one side and bank profitability on the other. Goddart et al. (2004) document a strong positive link between profitability and business cycle ${ }^{3}$, however this result is not always confirmed by other studies (Demirguc-Kunt and Huizinga, 1999).

Many recent studies take into account the large share of foreign bank assets in transition countries and include foreign ownership characteristic as one of the profitability determinants (Bonin et al., 2005; Demirguc-Kunt and Huizinga, 1999; Majnoni et. al, 2003; Chmielewski and Krzesniak, 2003). However, most of these studies assume that domestic and foreign bank profitability is influenced by the same factors, and perform their analysis on the pooled data. In reality, foreign banks are subject to two processes. Besides competing with domestic banks in their host countries they are part of multinational institutions and, therefore, can be affected by business conditions in their home countries and by strategy decisions of parent banks.

The theories of multinational banking can be broadly divided into a defensive expansion theory and positivist theories (see Curry, 2003, for a comprehensive survey of literature). The defensive expansion hypothesis suggests that foreign banks follow their clients into foreign markets (Grubel, 1977). The positivist theories include eclectic and internalization theories of multinational banking (see Williams, 1997, for a debate on these theories), and their underlying idea is that banks expand abroad in the quest to maximize their size and/or profits, as well as to diversify risk. Grubel (1977) asserts that foreign banks must also posses a comparative advantage in the foreign markets, which can be acquired thought years of competing in a sophisticated domestic market, previous experience in multinational banking or past operations in a similar foreign market (Tschoegl, 1982).

Williams (1998a, 1998b, 2003) constructs an empirical model of profit determinants of foreign banks and tests a number of hypotheses concerning size and profitability of foreign banks in Australia. The results of these studies show that domestic factors add only a limited descriptive power to the model, even though they offer important insights into strategic and policy decisions of foreign banks (Williams, 2003). Among international factors affecting foreign banks in Australia the most important are home GDP growth ${ }^{4}$ (Williams, 2003) and home NIM (Williams, 1998a), which have a positive impact on profits of foreign banks in Australia. There is also a limited support for the defensive expansion hypothesis, especially for the short period after the opening of the Australian banking market to foreign bank entry.

A number of papers investigate the relationship between assets growth and profitability. It is natural to assume that an efficient bank might decide to cut its prices, and thus gain an additional market share. Alternatively, it might choose to convert its superior efficiency into higher profits, forgoing the opportunity for growth (Goddart et al., 2004). This is a particularly important issue for foreign banks that might be interested in gaining a larger

\footnotetext{
${ }^{3}$ This is not surprising since during macroeconomic upswings borrowers' ability to repay loans tends to increase, and conversely, during downturns, loan defaults are likely to grow. Since loan loss provisioning is usually backward looking, and it is a key contributor to bank's earnings, we can expect a positive relationship between GDP growth and profitability (Hoggarth and Pein, 2002).

${ }^{4}$ The literature on the relationship between home countries conditions and loan growth of foreign banks is much larger, but the evidence that it provides is ambiguous. Peek and Rosengren (1997) and Jeanneau and Micu (2002) document positive relationship between home country GDP growth and expansion abroad, whereas de Haas and Lelyveld (2003) provide prove to the contrary and show that when banks face problems at home, they try to diversify and expand abroad.
} 
market share, and a few papers show that foreign banks in transition and developing countries exhibit higher and less volatile loan growth that continues even during crisis periods (de Haas and Lelyveld, 2003; Goldberg et al., 2002). Even though Goldberg et al. (2002) do not focus on the trade-off between profitability and loan growth, they document that higher and less volatile loan growth of foreign banks in Argentina and Mexico is attributed to general bank health characteristics rather then to ownership per se.

DeYoung and Nolle (1996) directly investigate the relationship between assets growth and profitability of foreign banks in the US and conclude that foreign banks might have placed growth ahead of profitability. The study shows that foreign banks do not succeed in developing a relationship with retail customers and therefore have to rely on expensive purchased funds. These results are also confirmed for the Australian market (Williams, 1998a, 1998b, 2003). Alternatively, Molyneux and Seth (1998) find that growth has a positive impact on profits of foreign banks in the US.

In the analysis of foreign banks, it is important to take into account the transition period, which would help to understand whether higher/lower profitability of foreign banks is acquired or created. However, most of the studies omit this question. The exception is the study of Peek and Rosengren (1999) that focuses on the transition period of foreign bank subsidiaries in the US and attempts to find explanation for their poor performance. Their results indicate that target banks of foreign acquirers exhibit lower profitability prior to the acquisition, during the transition period, and in the long run after the change of ownership. Contrasting results are presented by Majnoni et al. (2003), whose study does not control for the years before the acquisition, but shows that the profitability of Hungarian banks increases in the first four years after the acquisition by foreign investors and remains positive in the long run.

De Haas and Naaborg (2005) present an interesting analysis of foreign banks in transition economies, which is based on focused interviews with managers of foreign parent banks, their affiliates, and central bank officials in the CEEC. They document a number of channels through which the conditions in the home country could have an affect on profitability of foreign subsidiaries. For example, the National Bank of Poland points out that due to the subdued economic situation in Germany, some German banks were transferring subsidiaries' profits to the German head office though extraordinarily high dividends. The Hungarian Central Bank mentions the scenario where a foreign bank, due to problems at the home market, may not be willing to provide capital support to its subsidiary. Additionally, the increased risk premium for the parent bank may be translated into higher funding costs for the local subsidiaries.

The literature on bank profitability is closely related to the literature on the determinants of bank net interest margin (NIM). From a wide pool of work on this topic one recent paper should be singled out that compares the determinants of NIM for foreign and domestic banks. Peria and Mody (2004) analyze the impact of the increased foreign bank ownership and the simultaneous increase in industry concentration on bank spreads for the South American countries. The findings show that foreign banks, in particular greenfield institutions, charge lower interest margins. One of the most interesting findings of this study is that foreign and domestic banks react differently to the same market developments: greater market concentration raises spreads more for domestic banks than for foreign ones.

In our paper we contribute to the above literature in a few ways. First, in our analysis of profitability we clearly differentiate between mode of entry of foreign banks, namely banks 
that established greenfield institutions and those that took over existing domestic banks. Second, we assume that foreign and domestic banks can react differently to the same profitability determinants, such as domestic macroeconomic situation, market structure, and level of banking sector development. Therefore, we construct separate econometric models for domestic, greenfield and takeover banks. Finally, we focus on transition countries and test a number of hypotheses, which have been already tested for developed countries, but might have different results in the CEEC.

\section{Data}

We use sample of 265 banks from 10 CEEC (Bulgaria, the Czech Republic, Estonia, Hungary, Latvia, Lithuania, Poland, Romania, Slovakia, and Slovenia) between 1995-2003. All balance sheet and income statement data is taken from Bureau van Dijk's BankScope database. We use unconsolidated statements whenever possible, and rely on consolidated statements otherwise. We include in our sample commercial and savings banks, and exclude investment banks, micro-finance banks and development banks. Merged banks are considered as two entities before the merger and one entity after the merger.

In order to answer our research question, it is crucial to obtain the appropriate information on bank ownership (the BankScope database lacks the historical ownership data). For the years 1994-2001 we use the information kindly provided by de Haas and Lelyveld from de Nederlandsche Bank. The bank ownership for the two remaining years was determined by us based on the banks' official publications and central banks' reports. During the whole investigated period bank was considered foreign in a certain year if at least $51 \%$ of its capital was owned by foreign investors. We differentiate further between the two types of foreign ownership, namely takeover banks (i.e. institutions that were taken over by foreign banks) and greenfield banks (foreign banks that started operations as start-ups).

In addition, we also used the BankScope database to obtain the financial information on parent banks. Due to the lack of historical information, we have identified the largest investor in the BankScope database, and have checked other sources (newspapers, banks' annual reports, central banks' publications) for information on change of owner in the past. In this case we relied on consolidated balance sheets and income statements, since we are interested whether the financial health of parent banks has an impact on subsidiaries in the CEEC. The numbers of domestic, greenfield, and takeover banks in our sample are reported in Table 3.

The data on macroeconomic variables was taken from the International Financial Statistics, indices of banking reforms in the CEEC from the EBRD Transition Report, and capitalization of stock markets from national stock exchanges. We use macroeconomic data for all host countries; besides we use data for home countries of foreign banks in our sample. Host country is defined as a country where a bank is operating, whereas home country is the country of its parent bank. We have the following home countries in our sample: Austria, Belgium, Denmark, Finland, Germany, Greece, Hungary, Japan, Latvia, Italy, the Netherlands, Portugal, Russia, Sweden, the UK, and the US. Since many parent banks are large multinational institutions that operate beyond their home countries, we also decided to use alternative definition of home area, and use macroeconomic data for the EU instead of individual home countries.

We perform necessary steps to ensure consistency of our dataset. First, we remove banks for which the BankScope does not report any financial information. We also eliminate 
observations with the $1 \%$ smallest and largest values of return on assets and capitalization ${ }^{5}$. As a result, we obtain the database with 1314 bank-year observations. Comparison with the data published by the central banks of the respective CEEC reveals that our dataset covers $84 \%$ of total banking assets on average. Table 4 presents correlation matrix between our variables.

Table 5 presents summary statistics of ROA for banks of three types of ownership: domestic, takeover, and greenfield. The data is presented for each host country separately, and we show number of observations, mean, standard deviation, and p-value of the t-test on equality of means. The results indicate that the average profitability of foreign banks is higher than the profitability of domestic banks. However, the results are clearly driven by greenfield banks that enjoy ROA at least twice the size of that for domestic banks. Takeover banks also enjoy profits higher than those of domestic banks, but the t-statistics on equality of means does not show a significant difference. Furthermore, the situation varies a lot across the countries. In Bulgaria, the Czech Republic, Estonia, Hungary, Latvia, and Slovakia, both takeover and greenfield banks show higher ROA than domestic banks. On the other hand, in Romania and Slovenia profits of foreign banks are not just lower than those for domestic banks but they are even negative.

In Table 6 we show profitability of foreign banks in the CEEC and profitability of their parent banks in their home countries. Again we present calculations for each host country separately, and we show number of observations, mean, standard deviation, and p-value of the t-test on equality of means. The results indicate that it is very profitable for foreign banks to diversify into the Central and Eastern European banking markets, because their subsidiaries in these countries earn higher profits than parent banks on their own. Again the situation is different across countries, and while it is profitable to invest in most of the countries, in some countries, such as Lithuania and Romania, the profits of foreign banks are negative.

\section{Econometric methodology}

We proceed in two steps. To answer the first question "Did foreign banks acquire more or less profitable institutions in the CEEC?”, we estimate a logit model with the year_of_takeover as a dependent variable:

$$
\text { year_of_takeover }{ }_{i j t}=\left\{\begin{array}{llll}
1 & \text { with } & \text { probability } & \operatorname{Pr}(\text { year_of_takeover } \\
0 & \text { with } & =1)=P \\
0 & \text { probability } & \operatorname{Pr}(\text { year_of_takeover } \\
i j t & =0)=1-P
\end{array}\right.
$$

We use a logistic distribution to define the logit model:

$$
\operatorname{Pr}\left(\text { year_of_takeover }_{i j t}=1\right)=\Lambda\left(\alpha^{\prime} x\right)=\frac{e^{\alpha^{\prime} x}}{1+e^{\alpha^{\prime} x}}
$$

with $x$ denoting the vector of explanatory variables and $\alpha$ the vector of coefficients.

Therefore, the first model that we estimate is the following:

$$
\begin{aligned}
& \operatorname{Pr}(\text { year_of_takeover } \\
& +i j t \\
& +\alpha_{4} \times h_{-} \text {inf }_{j t}+\alpha_{5} \times \text { REER }_{j t}+\alpha_{6} \times h_{-} g d p_{j t}+\alpha_{7} \times h_{-} \text {irate }_{j t}+\alpha_{8} \times \text { credit }_{j t}+\alpha_{9} \times E B R D_{j t}+ \\
& \left.+\alpha_{10} \times \text { stock }_{j t}+\alpha_{11} \times \text { share }_{i j t}+\alpha_{12} \times H H I_{j t}+\alpha_{13} \times \text { crisis }_{j t}\right)
\end{aligned}
$$

\footnotetext{
${ }^{5}$ This step is motivated by the quality of data. Some of the values of ROA and NIM were absurd and therefore we decided to trim the data in order to exclude unreasonable values of variables.
} 
where the variables are explained in Table 7.

The estimation is performed on the pooled sample without fixed effects, because logit estimation with fixed effects would lead to the deletion of banks that have not been taken over $^{6}$. Our sample includes all banks except greenfield because this type of banks, by definition, has never been acquired by foreign investors. Three models are estimated with dependent variables for the year of takeover, the year before takeover and two years before takeover.

In order to answer the remaining four questions, we investigate the relationship between banks' return on assets and five groups of variables: a) individual banks' characteristics; b) host country macroeconomic conditions; c) indicators of financial structure development in host countries; d) parent banks’ performance indicators; e) home country macroeconomic conditions.

The baseline model that we test takes the following form:

$$
\begin{aligned}
\text { ROA }_{i j t}= & \beta_{0}+\beta_{1} \times \text { loan }_{-} g r_{i j t}+\beta_{2} \times h_{-} \text {cap }_{i j t}+\beta_{3} \times h_{-} \text {inf }_{j t}+\beta_{4} \times R E E R_{j t} \\
& +\beta_{5} \times h_{-} \text {gdp }_{j t}+\beta_{6} \times h_{-} \text {irate }_{j t}+\beta_{7} \times \text { credit }_{j t}+\beta_{8} \times E B R D_{j t}+\beta_{9} \times \text { stock }_{j t} \\
& +\beta_{10} \times \text { share }_{i j t}+\beta_{11} \times H H I_{j t}+\beta_{12} \times \text { foreign }_{i j t}+\beta_{13} \times \text { crisis }_{j t}+\beta_{14} \times p_{-} N_{i M_{i j t}} \\
& +\beta_{15} \times p_{-} \text {cap }_{i j t}+\beta_{16} \times p_{-} \text {gdp } p_{i j t}+\beta_{17} \times p_{-} \text {irate }_{i j t}+\eta_{i}+\mu_{j}+\gamma_{t}+\operatorname{hom} e_{i j t}^{\prime}+\varepsilon_{i j t}
\end{aligned}
$$

where the variables are explained in Table 7.

An estimation of the above equation with the OLS may be simple, but in our case would be deceiving. Taking into account our data characteristics, it is plausible to assume that the level of dependent variable consistently varies with the cross-section (i.e. bank), home/host country or time period. As a result, it is necessary to use appropriate panel data techniques.

The first step in our analysis is to ascertain the nature of bank-specific effects, i.e. to determine whether they are correlated with explanatory variables. This issue is very important as the improper specification of individual effects can result in estimates that are biased and inconsistent. In order to determine the nature of individual effects, we perform a Hausman test ${ }^{7}$. Its results indicate (for all specifications) that the individual effects are indeed correlated with independent variables. Hence, we choose a fixed effect model, controlling for bankspecific effects. Additionally, in all specifications we include dummies that control for home country-, host country-, and time-specific effects.

Next issue that we need to tackle is the possibility of heterogeneity and autocorrelation in the error term. We perform two tests: a modified Wald test for group-wise heteroscedasticity and the Wooldridge (2002) test for serial correlation. The obtained statistics indicate that both the variance of error terms is not constant across banks and that there is autocorrelation of order 1 (i.e. an AR1 process) in the residuals. Consequently, we choose the fixed effect model with Newey-West standard errors and an AR1 process in the error terms.

\section{Empirical results}

In this section we attempt to answer the questions that we posed in the Introduction.

\footnotetext{
${ }^{6}$ Since only 56 banks were taken over by foreign investors in our sample, the number of observations would shrink from 912 to 314.

${ }^{7}$ The values of Hausman tests are reported in the last line of Tables 9-10.
} 


\section{Did foreign banks acquire more or less profitable institutions?}

Descriptive statistics in Table 5 show that takeover banks enjoy ROA of $0.51 \%$, whereas domestic banks earn return of $0.45 \%$. Therefore, the obvious question that comes to mind is whether foreign banks earned their higher profitability or they inherited it when they took over a bank. To answer this question we run logit regression and present the results in Table 8. We estimate three models with dependent variables for the year of takeover (first model), the year before takeover (second model) and two years before takeover (third model).

The estimation has low explanatory power and the significance of coefficients is not consistent for the three estimated models. However, it still allows us to make conclusions about institutions which were acquired by foreign investors. First of all, foreign investors looked for banks with large market share, as this variable is positive and strongly significant across all models. Second, we can conclude that timing of acquisitions was important, since domestic banks were acquired during economic downturns when their profitability was low. This reflects the situation in some of the CEEC, where foreign banks were restricted to taking over only failing institutions (Poland between 1993-1997) or were allowed to enter only after the crises (Bulgaria and Romania). Interestingly, two years prior to takeovers profitability of target banks was significantly higher than one for the banks that remained domestic.

Our next step is to investigate profit determinants separately for all, domestic, greenfield, and takeover banks. The results are presented in Table 9 .

Before moving to the second question of our research, we would like to comment on the results for all banks. There are two columns entitled All banks, and in the first column we include dummy foreign to analyze the effect of foreign ownership on ROA, as it is usually done in the literature, and in the second column we include dummies greenfield and takeover to control for the mode of entry of foreign banks. The results of these two regressions show that greenfield banks exhibit higher profitability than domestic banks, whereas the effect of takeover dummy is not statistically significant. Among other determinants, we observe the positive effect of capitalization, inflation, GDP growth, market concentration and banking sector reform, whereas loan growth and capital market capitalization have a negative impact on ROA. These results are in line with the profitability literature, and therefore are not discussed in depth in this paper.

Are foreign and domestic banks affected in the same way by macroeconomic conditions in their host countries?

One of the advantages of foreign bank ownership could be their smaller sensitivity to macroeconomic conditions in their host countries. To test this hypothesis we included such variables as GDP growth, inflation, real interest rate, and change in real effective exchange rate in host countries. Now we compare the results for domestic banks (column 3, Table 9) and foreign banks (column 4, Table 9). Moreover we can compare results between greenfield banks (column 5, Table 9) and takeover banks (column 5, Table 9). As expected, domestic banks react positively to business cycles and this effect is significant at the $1 \%$ level. In support of our hypothesis, foreign banks are not influenced by business cycles of their host countries. Moreover, GDP growth affects profitability of greenfield banks in countercyclical manner: greenfield banks have higher ROA during economic downturns, and lower ROA during upswings. There can be a few possible reasons for this phenomenon. First, greenfield banks might charge higher interest rates during economic downturns to substitute for the increased risk, which would lead to higher profits if all other things are equal (Peria et al., 
2004). Second, they can use their loan loss provisions counter-cyclically, increasing them during good times and decreasing them during bad times. Finally, greenfield banks might receive more support from their parent banks during economic downturns in host countries. This can be related to strategy of greenfield banks to increase their market shares during economic downturns, when domestic banks usually contract their lending (de Haas and Lelyveld, 2005).

As to other macroeconomic variable, such as inflation, we also observe different reaction of domestic and foreign banks. Profits of domestic banks are not affected by inflation, whereas we observe a positive relationship between ROA of greenfield banks and inflation. Our finding that profits of some banks react positively to inflation confirms other profitability studies, and it is a well-known fact that adroitly managed banks profit from inflation due to the lag between raising their lending and deposit rates.

All banks except greenfields react positively to changes in the REER. It was difficult to foresee the direction of this relationship from balance sheets analysis of banks, because the assets and liabilities in foreign currency were in proportion to each other in most countries. Since, the data on maturity of these items was not available, and given that a large part of both assets and liabilities was denominated in foreign currency, the real effect of currency fluctuations on profits was unpredictable (Baudino et al., 2004). In addition to this direct impact, banks could have suffered from movements of foreign currency indirectly. During the analyzed period, most local currencies in our samples appreciated and this might have made it more difficult for exporting clients to repay loans, affecting banks' profits. As our results show, the banks in the CEEC have benefited from appreciation of their currencies, suggesting that their foreign currency liabilities had longer maturity than assets ${ }^{8}$. The reason why greenfield banks are not influenced by exchange rate fluctuations can be attributed to the use of instruments hedging against foreign exchange risks.

Are foreign banks sensitive to macroeconomic conditions in their home countries and to financial situation of their parent banks?

In order to answer this question we included characteristics of parent banks and home countries of parent banks into our econometric model. Our findings show that foreign banks in the CEEC are not sensitive to economic situation in their home countries. Since the majority of foreign banks that are present in the CEEC belong to multinational institutions that operate beyond their home countries, it would be more correct to include macroeconomic variables for the whole EU, and not for individual countries. We present the results of this specification in Table 10 (columns 1-3), but still we do not observe any significant impact of home area economic conditions on performance of foreign banks.

Concerning the financial situation of the parent banks, our findings show that greenfield banks are affected by strategies pursued by their parent banks. In fact we observe that greenfield banks in the CEEC improve their profitability when NIM of their parent banks goes down. This finding contradicts results of Williams (2003) who observe a positive relationship between ROA of foreign banks and NIM of their parent banks, explaining that only profitable banks can channel funds to their subsidiaries. However, low parent NIM can also result from the lack of profitable opportunities in the home market or very competitive banking environment. Therefore, such banks could seek opportunities abroad, explaining the

\footnotetext{
${ }^{8}$ As it was pointed to us by Iikka Korhonen, our results can be explained by the fact that exchange rate appreciation is usually associated with all kinds of positive developments in the economy, higher credibility of economic policies, better institutions, etc.
} 
negative coefficient of parent NIM in our regression. Such finding is logical in light of statements of managers of international banks who admit that they allocate capital to the subsidiaries with the highest expected returns (de Haas and Naaborg, 2005). We have also estimated our model with parent ROA as an explanatory variable, and the coefficient turns out to be positive albeit not significant (columns 4-6 of Table 10). This gives further support to our hypothesis that low NIM is the sign of the high competition and not of the low profitability.

Does market concentration in host countries have the same impact on foreign and domestic banks?

The increase in foreign bank ownership in the CEEC went hand in hand with the increased banking market concentration. It is a well known fact that banks earn higher profits in more concentrated markets. In our study we would like to see whether there are differences in the way foreign and domestic banks react to higher market concentration or their own market share. It is particularly interesting in our case, because the foreign ownership contributed to higher concentration of banking markets through two channels: 1) foreign banks acquired a few domestic institutions and merged them into one; 2) domestic institutions decided to consolidate due to competitive pressures from their foreign peers.

Similar to our previous findings, we observe differences in reaction of domestic and foreign banks. Domestic banks enjoy higher profits in more concentrated markets, indicating that structure-conduct-performance paradigm holds for them. At the same time foreign banks do not seem to profit from the above-mentioned factors, and the results hold true for takeover and greenfield banks. Our results are in line with Peria and Mody (2004), who in their study of foreign and domestic banks in Latin America have documented that greater market concentration raises spreads more for domestic banks than for foreign ones.

Which effect does the stage of banking sector reform and development of financial market have on profitability?

The level of financial sector development can also have a significant impact on bank profitability, and we include variables credit to the private sector and EBRD banking sector reform to capture the impact of banking sector development and variable stock market capitalization to see the impact of capital market development. In addition, we include the variable crisis to control for the periods of crises and banking restructuring with massive government recapitalizations.

Deeper banking markets (where ratio of credit to the private sector to GDP is higher) might signify more intense competition and therefore have a negative impact on bank profits (Demirguc-Kunt and Huizinga, 1999). In our case we find a positive impact of level of credit market development on foreign banks. The plausible explanation for this is that foreign banks can successfully use their knowledge in more developed markets, which are similar to markets in their home countries. There is anecdotal evidence that foreign banks rely more on hard information, whereas domestic banks have the advantage to be able to use soft information. As banking markets become deeper, the amount and quality of hard information increases, giving a comparative advantage to foreign banks. 
We also find that banks in countries with more advanced banking reforms enjoy higher profits $^{9}$ and this effect is particularly large for takeover banks. The reason why greenfield banks do not react to changes in EBRD banking reform index probably stems from the fact that these banks rely on internationally recognized standards even when they are not required to do so by the legislation of their host country.

Capital markets can serve a complementary or a substitution function to banking sector. On the one hand, the Miller-Modigliani theorem states that debt and equity finance are pure substitutes in the absence of taxes and bankruptcy costs. Therefore, we could expect a negative impact of deep stock markets on banks' profits, especially for foreign banks often accused of cherry-picking the blue-chip clients (substitution effect). On the other hand, if capital markets develop, banks have more information about clients, which makes the tasks of selecting and monitoring clients easier. Therefore, deep stock markets could help to mitigate problems of adverse selection and moral hazard and increase banks' profits (complementary effect). Our finding of negative association between profits of all types of bank ownership and stock market capitalization shows that the substitution effect dominates. Interestingly, there is no difference in the reaction of foreign and domestic banks.

Finally, we document the positive impact of the variable crisis on domestic banks, which is explained by the massive recapitalizations that affect domestic banks during crises. At first, the positive impact of this variable can seem puzzling, but it can be easier understood if we look at our correlation matrix (Table 4). In fact, simple correlation coefficient between crisis and ROA does not differ significantly from zero. At the same time we observe positive and significant correlation between crisis dummy and such variables as loan growth, inflation, interest rates, market concentration, and depth of banking and stock markets. Stage of the banking sector reform and GDP growth are negatively correlated with crisis dummy. So we can conclude that all negative consequences of the banking crises can be captured by the above variables, whereas the only factor for which we do control is bank recapitalizations. Since many countries recapitalized their banks during crises, we capture the positive effect of recapitalization rather than the negative impact of banking crises.

\section{Summary}

This paper contributes to the literature on benefits and costs of foreign bank ownership in transition economies. We investigate the determinants of banks' profitability using a dataset comprising 265 banks from 10 CEEC between 1995-2003. Our interest lies in the profitability determinants of banks with different ownership, hence we estimate the regressions for the whole sample and for the domestic, foreign, takeover, and greenfield banks separately. We study the relationship between banks' return on assets and five groups of variables: a) individual banks' characteristics; b) host country macroeconomic conditions; c) indicators of financial sector development in host countries; d) parent banks' performance indicators; e) home country macroeconomic conditions for parent banks.

Our findings show that greenfield banks perform better in terms of ROA than domestic and takeover banks. Interestingly, the profitability of takeover banks is not significantly different from domestic banks. This finding is surprising in light of previous literature which shows that foreign banks possess superior technology and are better in mitigating risks. However, it

\footnotetext{
${ }^{9}$ The index of banking reforms is taken from EBRD Transition report. The countries are classified into categories depending on how close their banking standards and norms are to those of advanced industrial economies and BIS standards, and whether they provide full set of competitive banking services.
} 
should be mentioned that most of the literature on foreign bank ownership does not differentiate between mode of foreign bank entry, namely greenfield and takeover banks. Our further analysis shows that relatively low profitability of takeover banks could be a consequence of the economic policy in some countries that allowed foreign bank entry only after crises. As a result, foreign banks took over less profitable institutions. We also find that it is profitable for international banks to open subsidiaries in transition economies, since ROA of foreign banks in the CEEC significantly exceeds the ratio of parent banks in home countries.

Our findings indicate that foreign banks possess one very important advantage in comparison to domestic banks, namely their profits are not negatively affected by economic downturns of their host countries. On the contrary, greenfield banks succeed to increase their profitability when GDP growth slows down in the CEEC, enhancing stability of the banking sector. However, the reasons for this phenomenon are not clear and there could be a few explanations of the counter-cyclical behavior of banks' profits. First, greenfield banks might charge higher interest rates during economic downturn to compensate for higher risk, and such strategy would have an adverse effect on companies. Second, greenfield banks might receive extra financing from their parent companies during economic downturns, contributing to the stability of credit supply. It would be an interesting and important question for a further analysis.

One of the possible dangers of foreign bank ownership is the dependence of foreign institutions on the performance of their parent banks and their sensitivity to macroeconomic conditions in their home countries. Our study does not find evidence to support these fears. To the contrary, our findings indicate that parent banks increase financing of their subsidiaries in CEEC if margins of parent institution decrease. Such finding is logical and it is also confirmed by managers of international banks who admit that they allocate capital to the subsidiaries with the highest expected returns.

The increase in foreign bank ownership in the CEEC went hand in hand with the increased banking market concentration. It is a well known fact that banks earn higher profits in more concentrated markets, which are usually associated with less competitive environment. However, our results show that profits of foreign banks are not affected by market concentration, whereas domestic banks find it more profitable to operate in such markets.

Our paper proves that it is very important not only to analyze separately foreign and domestic banks, but it necessary to distinguish between two modes of entry of foreign banks: establishing a greenfield institution, or taking over an existing domestic banks. Most of the literature on foreign banks ignore this division, but our study shows that profits of takeover and greenfield banks are influenced by different factors. Of course, the present paper is not without the usual shortcomings. The most important drawback is the lack of possibilities to distinguish the channels through which various profitability determinants affect greenfield, takeover and domestic banks. It would also be interesting to compare profitability determinants of foreign banks in the CEEC with those in other areas with high foreign bank presence, such as Latin America and Asia. 


\section{References}

Baudino, P., Caviglia, G., Dorrucci, E., Pineau, G., 2004. Financial FDI to the EU accession countries, ECB, publication of the BIS Committee on the Global Financial System.

Berger, A., 1995. The profit-structure relationship in banking - tests of market power and efficient-structure hypotheses. Journal of Money. Credit and Banking, 27 (2), 404431.

Berger, A., Clarke, G., Cull, R., Klapper, L., Udell., G., 2005. Corporate governance and bank perforamnce: a joint analysis of the static, selection, and dynamic effects of domestic , foreign, and state ownership. Journal of Banking and Finance 29, 21792221.

Berger, A., Demirguc-Kunt, A., Levine, R., Haubrich, J. G., 2004. Bank concentration and competition : an evolution in the making. Journal of Money, Credit and Banking, vol. 36, No. 3, pp. 433-451.

Berger, A., Hannan T., 1998. The efficiency cost of market power in the banking industry: a test of the "quiet life" and related hypotheses. Review of Economics and Statistics 80, 454-465.

Bonin, J.P., Hasan, I., Wachtel, P., 2005. Bank performance, efficiency and ownership in transition countries. Journal of Banking and Finance, 29, 31-53.

Chmielewski, T., Krzesniak, A., 2003. Individual characteristics influencing bank profitability in Poland. Financial Stability Report , National Bank of Poland.

Claessens, Stijn, DemirgÄu»c-Kunt, Asli, Huizinga, Harry, 2001. How does foreign entry affect domestic banking markets? Journal of Banking and Finance 25, 891-911.

Claessens, S., Laeven, L., 2004. What drives bank competition? Some international evidence. Journal of Money, Credit and Banking 36 (3), pp. 563-584.

Curry, E., Fung, J., Harper, I.R., 2003. Multinational banking: historical, empirical and case perspectives. In A.W. Mullineux and V. Murinde (eds.), Handbook of International Banking, Edward Elgar, UK and USA, pp. 27 - 59.

Demirguc-Kunt, A., Huizinga, H., 1999. Determinants of commercial bank interest margins and profitability: some international evidence. The World Bank Economic Review, 13(2), 379-408.

DeYoung, R., Nolle, D., 1996. Foreign-owned banks in the United States: earning market share or buying it? Journal of Money, Credit and Banking, Vol. 28, No. 4, Part 1, 622-636.

Gilbert, R., 1984. Bank market structure and competition: a survey. Journal of Money, Credit, and Bnaking 16, pp. 617-660.

Gonzalez, F., 2004. Do equity investments affect banks' profitability? Evidence from OECD countries. Applied Financial Economics, v. 14, iss. 15, pp. 1111-24

Grubel, H., 1977. A theory of multinational banking. Banca Nazionale del Lavoro. Quarterly Review 123, 349-63.

De Haas, R and I. van Lelyveld, 2005. Foreign banks and credit stability in Central and Eastern Europe: friends or foes? Forthcoming in the Journal of Banking and Finance.

De Haas, R and I. Naaborg, 2005. Internal capital markets in multinational banks: implications for European transition countries. DNB Working Paper No. 51.

Hoggarth, G., Pain, D., 2002. Bank provisioning : the UK experience. Financial Stability Review. Bank of England, pp116-127. 
Kosmidou, K., Pasiouras F., Floropoulos, J., 2004. Linking profits to asset-liability management of domestic and foreign banks in the UK. Applied Financial Economics, 2004, vol. 14, issue 18, pages 1319-1324.

Jeanneau, S. and M. Micu, 2002. Determinants of international bank lending to emerging market countries, BIS Working Papers No. 112.

Majnoni, G., Shankar, R., Varhegyi, E., 2003. The dynamics of foreign bank ownership. Evidence from Hungary. World Bank Policy Research Working Paper No 3114.

Mian, A., 2005. Distance constraints: the limits of foreign lending in poor economies, forthcoming in Journal of Finance.

Peek, J., and Rosengren, E., 1997. The international transmission of financial shocks: the case of Japan, American Economic Review 87 (4), 495-505.

Peek, J., Rosengren, E., Kasirye, F., 1999. The poor performance of foreign bank subsidiaries: Were the problems acquired or created? Journal of Banking and Finance 23, pp579-604.

Peek, J., Rosengren, E., 2000. Collateral damage: effects of the Japanese bank crisis on real activity in the United States. American Economic Review 90, pp 30-45.

Peria, M. S. M., Mody, A., 2004. How foreign participation and market concentration impact bank spreads : evidence from Latin America. Journal of Money, Credit and Banking, vol. 36, No. 3, pp. 511-537.

Tang, H., Zoli, E., Klytchnikova I., 2000. Banking crises in transition economies. Fiscal costs and related issues, World Bank Policy Research Working Paper No. 2484.

Tschoegl, A., 1982. Foreign bank entry into Japan and California. In Rugman, A. (Ed.), New Theories of multinational Enterprise. London, Croom Helm, pp. 196-216.

Williams, B., 1998a. Factors affecting the performance of foreign-owned banks in Australia : a cross-sectional study. Journal of Banking and Finance 22, 197-219.

Williams, B., 1998b. A pooled study of the profits and size of foreign banks in Australia. Journal of Multinational Financial Management 8, 211-231.

Williams, B., 2003. Domestic and international determinants of bank profits: foreign banks in Australia. Journal of Banking and Finance 27, 1185-1210.

Wooldridge, J. M., 2002. Econometric analysis of panel data, The MIT Press, Cambridge, Massachusetts. 
Table 1. The share of foreign capital in the CEEC between 1995-2003

\begin{tabular}{|c|c|c|c|c|c|c|c|c|c|}
\hline & 1995 & 1996 & 1997 & 1998 & 1999 & 2000 & 2001 & 2002 & 2003 \\
\hline Bulgaria & N.A. & N.A. & 34.8 & 43.4 & 46.6 & 68.1 & 66.7 & 66.6 & 76.3 \\
\hline Czech Republic & 22.8 & 24.1 & 29.5 & 38.7 & 48.4 & 54.5 & 70 & 81.9 & 84.9 \\
\hline Estonia & 29.2 & 37.2 & N.A. & 55.49 & 62.23 & 83.91 & 85.74 & 86.73 & 85.7 \\
\hline Hungary & 35.6 & 45.9 & 61.2 & 60.4 & 62.1 & 64 & 61 & 58.6 & 81.9 \\
\hline Latvia & 27.7 & 55.6 & 67.7 & 66.2 & 69.8 & 69.8 & 67.7 & 54.3 & 53.9 \\
\hline Lithuania & 16 & 25 & 32 & 41.3 & 45.3 & 59.9 & 82.3 & 88 & 88 \\
\hline Poland & 19.24 & 29.79 & 41.52 & 49.7 & 56 & 56.6 & 61.3 & 63.2 & 63.3 \\
\hline Romania & 14.11 & 12.84 & 24.46 & 35.79 & 41.75 & 53.8 & 60.6 & 64.9 & 66.3 \\
\hline Slovakia & N.A. & 39.6 & 39.2 & 37.3 & 24.6 & 28.1 & 60 & 85.3 & 88.9 \\
\hline Slovenia & 9.59 & 9.16 & 11.88 & 11.13 & 11.3 & 12 & 16 & 32.5 & 32.5 \\
\hline
\end{tabular}

Source: BSCEE review 
Table 2. Market shares (in \%) and total assets (in th EURO) of major international banks in the CEEC in 2003

\begin{tabular}{|c|c|c|c|c|c|c|c|c|c|c|c|}
\hline & Market & t shares & $\mathrm{s}$ in eacl & h count & try (in $\%$ & $\%$ of tot & tal coun & try ban & $\mathrm{nk}$ asset & & Total assets \\
\hline & BG & $\mathrm{CZ}$ & $\mathrm{EE}$ & $\mathrm{HU}$ & $\mathrm{LT}$ & $\mathrm{LV}$ & PL & RO & SI & SK & $\begin{array}{l}\text { in the CEEC } \\
\text { (in th. EUR) }\end{array}$ \\
\hline KBC Bank NV & & 25.48 & & 10.2 & & & 5.24 & & & & 30287910.3 \\
\hline Erste Bank Sparkasse & & 25.88 & & 6.77 & & & & & & 24.26 & 28534848.9 \\
\hline HVB Group & 10.13 & 5.55 & & 5.66 & 2.75 & & 10.77 & 3.4 & 4.21 & 5.74 & 22196820.6 \\
\hline Societe Generale & 4.01 & 19.18 & & & & & & 15.2 & 7.51 & 0.43 & 19116304.9 \\
\hline Unicredito Italiano & 17.11 & 2.06 & & & & & 14.03 & 1.32 & & 4.51 & 18746734.5 \\
\hline Raiffeisen & 5.13 & 3.86 & & 5.9 & & & 1.96 & 7.94 & 2.35 & 20.97 & 14762549.2 \\
\hline Citibank a.s. & & 2.94 & & 2.58 & & & 7.58 & 3.14 & & 3.05 & 12463970.1 \\
\hline Banca Intesa SpA & & & & 7.58 & & & & & & 22.28 & 8760961.68 \\
\hline ING Bank NV & 1.32 & & & 2.27 & & & 6.45 & & & & 7932755.62 \\
\hline Commerzbank AG & & & & 1.04 & & & 6.72 & & & & 7410738.56 \\
\hline Swedbank & & & 62.8 & & 28.82 & 17.5 & & & & & 6929075.57 \\
\hline Allied Irish Banks plc & & & & & & & 5.38 & & & & 5478194.61 \\
\hline Skandinaviska Enskilda & & & 26.8 & & 38.46 & 16.2 & & & & & 5248655.36 \\
\hline Bayerische Landesbank & & & & 8.12 & & & & & & & 4413335.91 \\
\hline Millennium & & & & & & & 4.32 & & & & 4399315.47 \\
\hline GE Capital Bank & & 2.43 & & 2.77 & & & & & & & 3358344.92 \\
\hline Oesterreich. Volksbanken & 14.45 & 0.80 & & 1.08 & & & & 0.98 & 1.30 & 3.17 & 2299759.63 \\
\hline San Paolo IMI & & & & 1.41 & & & & 0.44 & 5.65 & & 2105390.66 \\
\hline ABN AMRO Bank & & & & & & & 0.75 & 5.65 & & & 1621319.39 \\
\hline Deutsche Bank & & & & 0.56 & & & 1.28 & & & & 1601328.95 \\
\hline Crédit Lyonnais & & 0.85 & & 0.89 & & & 0.28 & & & 0.87 & 1600961.57 \\
\hline National Bank of Greece & 10.94 & & & & & & & 1.18 & & & 1302810.6 \\
\hline BNP Paribas & 1.47 & & & 1.10 & & & 0.52 & & & & 1275444.42 \\
\hline Bank für Arbeit und Wirtsch. & & 0.59 & & & & & & & & 3.22 & 1120549.06 \\
\hline Gazprombank Group & & & & 2.01 & & & & & & & 1094768.34 \\
\hline NORD/LB & & & & & 12.43 & 4.04 & & & & & 1077680.99 \\
\hline Fortis & & & & & & & 1.02 & & & & 1039485.02 \\
\hline Credit Agricole & & & & 0.06 & & & 0.88 & & & & 934484.246 \\
\hline Nordea & & & & & & & 0.90 & & & & 917856.657 \\
\hline WestLB & & & & 0.68 & & & 0.48 & & & & 862762.533 \\
\hline Rabobank & & & & & & & 0.81 & & & & 828800.036 \\
\hline EFG Eurobank Ergasias & & & & & & & & 4.95 & & & 748297.926 \\
\hline Sampo Bank Plc & & & 7.67 & & 3.80 & 0.46 & & & & & 726243.31 \\
\hline DEXIA & & & & & & & & & & 3.08 & 640902.475 \\
\hline Alpha Bank & & & & & & & 3.98 & & & & 601215.733 \\
\hline Dresdner Bank AG & & 0.78 & & & & & & & & & 593741.997 \\
\hline Hypo Alpe-Adria Bank AG & & & & & & & & & 1.60 & & 360962.134 \\
\hline Danske Bank A/S & & & & & & & 0.28 & & & & 281109.751 \\
\hline United Gulf Bank & & & & & & 2.99 & & & & & 242900.302 \\
\hline Korea Development Bank & & & & 0.41 & & & & & & & 222081.081 \\
\hline DZ Bank AG & & & & & & & 0.21 & & & & 214696.949 \\
\hline MDM Bank & & & & & & 2.5 & & & & & 203021.148 \\
\hline Piraeus Bank & & & & & & & & 1.16 & & & 176008.215 \\
\hline Bank of Tokyo - Mitsubishi & & & & & & & 0.11 & & & & 115168.412 \\
\hline Emporiki Bank of Greece & 0.51 & & & & & & & 0.36 & & & 106824.435 \\
\hline Meinl Bank AG & & & & & & & & & & 0.41 & 85684.1339 \\
\hline GMAC Bank & & & & 0.07 & & & & & & & 40266.0618 \\
\hline Bank of Moscow & & & & & & 0.39 & & & & & 31873.1118 \\
\hline Egnatia Bank & & & & & & & & 0.18 & & & 27933.0444 \\
\hline Total foreign assets & 65.06 & 90.4 & 97.4 & 61.19 & 86.25 & 44.1 & 73.97 & 45.9 & 22.62 & 91.98 & \\
\hline
\end{tabular}

Source : BankScope and authors’ calculations 
Table 3. Number of greenfield, takeover and domestic banks in the sample for each country during 1995-2003

\begin{tabular}{rlrrrrrrrrr}
\hline & & 1995 & 1996 & 1997 & 1998 & 1999 & 2000 & 2001 & 2002 & 2003 \\
\cline { 3 - 10 } Bulgaria & & & & & & & & & & \\
& Greenfield & & & 3 & 3 & 4 & 5 & 5 & 5 & 5 \\
& Takeover & & & & 1 & 3 & 5 & 7 & 8 & 10 \\
& Domestic & 5 & 6 & 10 & 19 & 14 & 16 & 13 & 13 & 11 \\
& Total & 5 & 6 & 13 & 23 & 21 & 26 & 25 & 26 & 26 \\
\hline
\end{tabular}

\begin{tabular}{lrrrrrrrrr}
\hline Czech Republic & & & & & & & & & \\
Greenfield & 6 & 11 & 12 & 10 & 12 & 12 & 11 & 10 & 8 \\
Takeover & & & & 2 & 2 & 3 & 5 & 6 & 6 \\
Domestic & 7 & 11 & 12 & 10 & 12 & 12 & 10 & 9 & 8 \\
Total & 13 & 22 & 24 & 22 & 26 & 27 & 26 & 25 & 22 \\
\hline
\end{tabular}

\begin{tabular}{|c|c|c|c|c|c|c|c|c|c|c|}
\hline \multicolumn{11}{|l|}{ Estonia } \\
\hline & Greenfield & & & & & & & & & \\
\hline & Takeover & & & & & 2 & 2 & 3 & 3 & 3 \\
\hline & Domestic & 7 & 9 & 11 & 4 & 2 & 3 & 2 & 3 & 4 \\
\hline & Total & 7 & 9 & 11 & 4 & 4 & 5 & 5 & 6 & 7 \\
\hline \multicolumn{11}{|l|}{ Hungary } \\
\hline & Greenfield & 5 & 12 & 14 & 12 & 17 & 17 & 12 & 13 & 13 \\
\hline & Takeover & & 4 & 7 & 8 & 8 & 10 & 11 & 12 & 11 \\
\hline & Domestic & 7 & 10 & 10 & 7 & 8 & 9 & 9 & 7 & 7 \\
\hline & Total & 12 & 26 & 31 & 27 & 33 & 36 & 32 & 32 & 31 \\
\hline
\end{tabular}

Lithuania

Greenfield

Takeover

$\begin{array}{llllllllll}\text { Domestic } & 2 & 2 & 10 & 10 & 6 & 6 & 3 & 2 & 2\end{array}$

\begin{tabular}{llllllllll} 
Total & 2 & 2 & 10 & 10 & 9 & 9 & 9 & 9 & 9 \\
\hline
\end{tabular}

\begin{tabular}{|c|c|c|c|c|c|c|c|c|c|c|}
\hline \multicolumn{11}{|l|}{ Latvia } \\
\hline & Greenfield & & & 1 & 1 & 1 & 1 & 2 & 2 & 2 \\
\hline & Takeover & & & 3 & 3 & 4 & 4 & 5 & 5 & 5 \\
\hline & Domestic & 5 & 10 & 19 & 17 & 15 & 15 & 12 & 14 & 14 \\
\hline & Total & 5 & 10 & 23 & 21 & 20 & 20 & 19 & 21 & 21 \\
\hline \multicolumn{11}{|l|}{ Poland } \\
\hline & Greenfield & 2 & 9 & 11 & 12 & 12 & 10 & 12 & 12 & 11 \\
\hline & Takeover & & 1 & 4 & 5 & 7 & 11 & 14 & 14 & 14 \\
\hline & Domestic & 20 & 29 & 28 & 23 & 24 & 19 & 15 & 13 & 12 \\
\hline & Total & 22 & 39 & 43 & 40 & 43 & 40 & 41 & 39 & 37 \\
\hline
\end{tabular}

\begin{tabular}{|c|c|c|c|c|c|c|c|c|c|c|}
\hline \multicolumn{11}{|l|}{ Romania } \\
\hline & Greenfield & 1 & & 1 & 7 & 9 & 8 & 8 & 9 & 9 \\
\hline & Takeover & & & & 1 & 2 & 2 & 4 & 5 & 8 \\
\hline & Domestic & 4 & 3 & 5 & 12 & 12 & 15 & 13 & 12 & 9 \\
\hline & Total & 5 & 3 & 6 & 20 & 23 & 25 & 25 & 26 & 26 \\
\hline \multicolumn{11}{|l|}{ Slovenia } \\
\hline & Greenfield & 2 & 4 & 5 & 4 & 4 & 4 & 4 & 4 & 4 \\
\hline & Takeover & & & & 1 & 1 & 1 & 1 & 2 & 2 \\
\hline & Domestic & 6 & 14 & 23 & 15 & 15 & 15 & 13 & 10 & 11 \\
\hline & Total & 8 & 18 & 28 & 20 & 20 & 20 & 18 & 16 & 17 \\
\hline \multicolumn{11}{|l|}{ Slovakia } \\
\hline & Greenfield & 1 & 6 & 8 & 8 & 7 & 8 & 6 & 6 & 6 \\
\hline & Takeover & & 1 & 1 & 2 & 2 & 2 & 5 & 7 & 8 \\
\hline & Domestic & 3 & 9 & 9 & 8 & 8 & 9 & 6 & 4 & 3 \\
\hline & Total & 4 & 16 & 18 & 18 & 17 & 19 & 17 & 17 & 17 \\
\hline Total & & 83 & 151 & 207 & 205 & 216 & 227 & 217 & 217 & 213 \\
\hline
\end{tabular}

Source: authors’ calculations. 
Table 4. Correlation matrix of variables

\begin{tabular}{|c|c|c|c|c|c|c|c|}
\hline & Roa & $\begin{array}{l}\text { Loan } \\
\text { growth }\end{array}$ & Capital & $\begin{array}{l}\text { host } \\
\text { inflation }\end{array}$ & reer & $\begin{array}{l}\text { private } \\
\text { credit }\end{array}$ & $\begin{array}{l}\text { stock } \\
\text { market }\end{array}$ \\
\hline loan growth & $\begin{array}{l}-\mathbf{0 . 0 4 5 5} \\
0.1046\end{array}$ & 1.0000 & & & & & \\
\hline capital & $\begin{array}{l}\mathbf{0 . 1 9 5 4} 4^{* * *} \\
0.0000\end{array}$ & $\begin{array}{l}\mathbf{0 . 0 7 0 1}^{\text {*** }} \\
0.0124\end{array}$ & 1.0000 & & & & \\
\hline host inflation & $\begin{array}{l}\mathbf{0 . 0 8 5 7}^{\text {****}} \\
0.0022\end{array}$ & $\begin{array}{l}-0.0028 \\
0.9216\end{array}$ & $\begin{array}{l}\mathbf{0 . 0 6 1 5} \\
0.0284\end{array}$ & 1.0000 & & & \\
\hline reer & $\begin{array}{l}0.0298 \\
0.2889\end{array}$ & $\begin{array}{l}0.0155 \\
0.5815\end{array}$ & $\begin{array}{l}0.0245 \\
0.3820\end{array}$ & $\begin{array}{l}\mathbf{0 . 1 5 6 3} \\
0.0000\end{array}$ & 1.0000 & & \\
\hline private credit & $\begin{array}{l}-0.0297 \\
0.2895\end{array}$ & $\begin{array}{l}0.0408 \\
0.1461\end{array}$ & $\begin{array}{l}-\mathbf{0 . 3 1 7 6} \\
0.0000\end{array}$ & $\begin{array}{l}-\mathbf{0 . 1 1 8 5} \\
0.0000\end{array}$ & $\begin{array}{l}\mathbf{- 0 . 1 1 1 7}^{\text {****}} \\
0.0001\end{array}$ & 1.0000 & \\
\hline stock market & $\begin{array}{l}\mathbf{- 0 . 1 2 2 8}^{* * *} \\
0.0000\end{array}$ & $\begin{array}{l}0.0311 \\
0.2673\end{array}$ & $\begin{array}{l}-\mathbf{0 . 3 1 4 4} \\
0.0000\end{array}$ & $\begin{array}{l}\mathbf{- 0 . 1 4 8 8}^{\text {****}} \\
0.0000\end{array}$ & $\begin{array}{l}-0.0183 \\
0.5140\end{array}$ & $\begin{array}{l}\mathbf{0 . 4 9 2 6}^{\text {****}} \\
0.0000\end{array}$ & 1.0000 \\
\hline share & $\begin{array}{l}\mathbf{0 . 0 7 4 9}^{* * *} \\
0.0075\end{array}$ & $\begin{array}{l}-0.0177 \\
0.5288\end{array}$ & $\begin{array}{l}\mathbf{- 0 . 0 9 6 0}^{* * *} \\
0.0006\end{array}$ & $\begin{array}{l}0.0021 \\
0.9396\end{array}$ & $\begin{array}{l}0.0009 \\
0.9753\end{array}$ & $\begin{array}{l}-0.0389 \\
0.1661\end{array}$ & $\begin{array}{l}\mathbf{0 . 0 4 7 1} \\
0.0934\end{array}$ \\
\hline HHI & $\begin{array}{l}-0.0329 \\
0.2409\end{array}$ & $\begin{array}{l}0.0121 \\
0.6661\end{array}$ & $\begin{array}{l}\mathbf{0 . 0 5 3 8}^{* *} \\
0.0551\end{array}$ & $\begin{array}{l}\mathbf{0 . 1 1 5 0} \\
0.0000\end{array}$ & $\begin{array}{l}-0.0340 \\
0.2261\end{array}$ & $\begin{array}{l}-\mathbf{0 . 0 5 9 4} \\
0.0343\end{array}$ & $\begin{array}{l}\mathbf{0 . 1 1 5 1}^{\text {***}} \\
0.0000\end{array}$ \\
\hline EBRD & $\begin{array}{l}\mathbf{0 . 0 5 5 0}^{* *} \\
0.0499\end{array}$ & $\begin{array}{l}-0.0435 \\
0.1212\end{array}$ & $\begin{array}{l}-\mathbf{0 . 2 5 0 1} \\
0.0000\end{array}$ & $\begin{array}{l}-\mathbf{0 . 1 5 0 7} \\
0.0000\end{array}$ & $\begin{array}{l}-\mathbf{0 . 0 5 0 9} \\
0.0696\end{array}$ & $\begin{array}{l}\mathbf{0 . 3 3 2 0} \\
0.0000\end{array}$ & $\begin{array}{l}\mathbf{0 . 5 1 1}^{\text {****}} \\
0.0000\end{array}$ \\
\hline host gdp & $\begin{array}{l}0.0255 \\
0.3630\end{array}$ & $\begin{array}{l}0.0080 \\
0.7756\end{array}$ & $\begin{array}{l}\mathbf{0 . 0 7 6 6}^{\text {****}} \\
0.0063\end{array}$ & $\begin{array}{l}-\mathbf{0 . 2 6 8 4} \\
0.0000\end{array}$ & $\begin{array}{l}\mathbf{- 0 . 0 6 8 1}^{\text {** }} \\
0.0152\end{array}$ & $\begin{array}{l}-\mathbf{0 . 1 7 4 3} \\
0.0000\end{array}$ & $\begin{array}{l}\mathbf{- 0 . 0 9 4 8}^{\text {****}} \\
0.0007\end{array}$ \\
\hline host interest rate & $\begin{array}{l}\mathbf{- 0 . 0 5 1 9}^{*} \\
0.0645\end{array}$ & $\begin{array}{l}0.0435 \\
0.1206\end{array}$ & $\begin{array}{l}-0.0136 \\
0.6279\end{array}$ & $\begin{array}{l}-\mathbf{0 . 6 3 6 1} \\
0.0000\end{array}$ & $\begin{array}{l}-\mathbf{0 . 3 2 6 4} \\
0.0000\end{array}$ & $\begin{array}{l}0.0430 \\
0.1252\end{array}$ & $\begin{array}{l}\mathbf{0 . 1 8 9 3}^{\text {*** }} \\
0.0000\end{array}$ \\
\hline crisis & $\begin{array}{l}0.0177 \\
0.5288\end{array}$ & $\begin{array}{l}\mathbf{0 . 0 8 2 7} \\
0.0032\end{array}$ & $\begin{array}{l}-0.0397 \\
0.1568\end{array}$ & $\begin{array}{l}\mathbf{0 . 1 8 4 3} \\
0.0000\end{array}$ & $\begin{array}{l}-0.0114 \\
0.6833\end{array}$ & $\begin{array}{l}\mathbf{0 . 2 9 0 9} \\
0.0000\end{array}$ & $\begin{array}{l}\mathbf{0 . 1 1 7 3}^{\text {***}} \\
0.0000\end{array}$ \\
\hline foreign & $\begin{array}{l}\mathbf{0 . 1 0 0 4} \\
0.0003\end{array}$ & $\begin{array}{l}0.0279 \\
0.3208\end{array}$ & $\begin{array}{l}-0.0232 \\
0.4093\end{array}$ & $\begin{array}{l}-0.0356 \\
0.2050\end{array}$ & $\begin{array}{l}-0.0450 \\
0.1090\end{array}$ & $\begin{array}{l}\mathbf{0 . 1 0 2 5} \\
0.0003\end{array}$ & $\begin{array}{l}\mathbf{0 . 1 9 0 0}^{\text {***}} \\
0.0000\end{array}$ \\
\hline greenfield & $\begin{array}{l}\mathbf{0 . 1 2 6 5} \\
0.0000\end{array}$ & $\begin{array}{l}0.0429 \\
0.1264\end{array}$ & $\begin{array}{l}0.0062 \\
0.8261\end{array}$ & $\begin{array}{l}0.0057 \\
0.8397\end{array}$ & $\begin{array}{l}0.0052 \\
0.8536\end{array}$ & $\begin{array}{l}\mathbf{0 . 1 4 0 1}^{\text {***}} \\
0.0000\end{array}$ & $\begin{array}{l}\mathbf{0 . 1 3 1 9}^{* * *} \\
0.0000\end{array}$ \\
\hline takeover & $\begin{array}{l}-\mathbf{0 . 0 6 3 5} \\
0.0235\end{array}$ & $\begin{array}{l}-0.0071 \\
0.8016\end{array}$ & $\begin{array}{l}0.0272 \\
0.3324\end{array}$ & $\begin{array}{l}-0.0161 \\
0.5668\end{array}$ & $\begin{array}{l}0.0387 \\
0.1678\end{array}$ & $\begin{array}{l}-\mathbf{0 . 0 8 5 7} \\
0.0022\end{array}$ & $\begin{array}{l}-0.0161 \\
0.5663\end{array}$ \\
\hline
\end{tabular}

Source: authors' calculations.

The table presents correlation coefficients and below p-values. 
Table 4. (continued)

\begin{tabular}{llllll} 
share & HHI & EBRD & host gdp & $\begin{array}{l}\text { host } \\
\text { interest rate }\end{array}$ & Forisis \\
\hline
\end{tabular}

\begin{tabular}{|c|c|c|c|c|c|c|c|c|}
\hline share & 1.0000 & & & & & & & \\
\hline HHI & $\begin{array}{l}\mathbf{0 . 3 8 2 2}^{* * *} \\
0.0000\end{array}$ & 1.0000 & & & & & & \\
\hline EBRD & $\begin{array}{l}-0.0329 \\
0.2412\end{array}$ & $\begin{array}{l}-\mathbf{0 . 2 3 4 1} \\
0.0000\end{array}$ & 1.0000 & & & & & \\
\hline host gdp & $\begin{array}{l}0.0278 \\
0.3214\end{array}$ & $\begin{array}{l}-\mathbf{0 . 1 2 2 2} \\
0.0000\end{array}$ & $\begin{array}{l}\mathbf{0 . 1 3 8 9}^{* * *} \\
0.0000\end{array}$ & 1.0000 & & & & \\
\hline host interest rate & $\begin{array}{l}-\mathbf{0 . 0 7 8 5} \\
0.0051\end{array}$ & $\begin{array}{l}-\mathbf{0 . 0 9 0 2} \\
0.0013\end{array}$ & $\begin{array}{l}0.0276 \\
0.3249\end{array}$ & $\begin{array}{l}-0.0019 \\
0.9467\end{array}$ & 1.0000 & & & \\
\hline crisis & $\begin{array}{l}-0.0110 \\
0.6958\end{array}$ & $\begin{array}{l}\mathbf{0 . 1 3 1 0}^{\text {***}} \\
0.0000\end{array}$ & 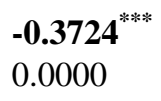 & $\begin{array}{l}-\mathbf{0 . 3 0 1 0} \\
0.0000\end{array}$ & $\begin{array}{l}\mathbf{0 . 1 4 2 3}^{\text {***}} \\
0.0000\end{array}$ & 1.0000 & & \\
\hline foreign & $\begin{array}{l}-\mathbf{0 . 0 6 9 6} \\
0.0131\end{array}$ & $\begin{array}{l}-\mathbf{0 . 1 2 1 7} \\
0.0000\end{array}$ & $\begin{array}{l}\mathbf{0 . 2 2 8 9}^{* * *} \\
0.0000\end{array}$ & $\begin{array}{l}\mathbf{- 0 . 0 5 5 7}^{* *} \\
0.0471\end{array}$ & $\begin{array}{l}\mathbf{0 . 0 9 1 3}^{\text {*** }} \\
0.0011\end{array}$ & $\begin{array}{l}-0.0204 \\
0.4662\end{array}$ & 1.0000 & \\
\hline greenfield & $\begin{array}{l}-\mathbf{0 . 2 0 7 2} \\
0.0000\end{array}$ & $\begin{array}{l}-\mathbf{0 . 1 3 1 9} \\
0.0000\end{array}$ & $\begin{array}{l}\mathbf{0 . 1 0 7 1}^{\text {****}} \\
0.0001\end{array}$ & $\begin{array}{l}-\mathbf{0 . 1 2 3 7} \\
0.0000\end{array}$ & $\begin{array}{l}\mathbf{0 . 0 6 3 6}^{* *} \\
0.0233\end{array}$ & $\begin{array}{l}\mathbf{0 . 0 6 4 0}^{* *} \\
0.0224\end{array}$ & $\begin{array}{l}\mathbf{0 . 6 8 1 4} \\
0.0000\end{array}$ & 1.0000 \\
\hline takeover & $\begin{array}{l}\mathbf{0 . 1 0 3 8}^{* * *} \\
0.0002\end{array}$ & $\begin{array}{l}\mathbf{0 . 0 5 5 6}^{\text {** }} \\
0.0473\end{array}$ & $\begin{array}{l}-0.0342 \\
0.2232\end{array}$ & $\begin{array}{l}-0.0113 \\
0.6883\end{array}$ & $\begin{array}{l}-0.0078 \\
0.7817\end{array}$ & $\begin{array}{l}\mathbf{- 0 . 0 6 0 1}^{* *} \\
0.0321\end{array}$ & 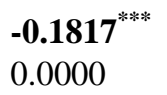 & $\begin{array}{l}-\mathbf{0 . 1 3 4 3} 3^{* * *} \\
0.0000\end{array}$ \\
\hline
\end{tabular}

Source: authors' calculations.

The table presents correlation coefficients and below p-values. 
Table 5. Summary statistics of ROA across countries

\begin{tabular}{|c|c|c|c|c|c|}
\hline & & Obs & Mean & $\mathrm{SE}$ & $\mathrm{p}$ \\
\hline \multicolumn{6}{|l|}{ BG } \\
\hline & Domestic & 107 & .6558566 & .2829711 & \\
\hline & Takeover & 34 & 1.454849 & .2518847 & $0.1285^{1)}$ \\
\hline & Greenfield & 31 & .6938736 & .5527204 & $0.9499^{2)}$ \\
\hline \multicolumn{6}{|l|}{$\overline{\mathrm{CZ}}$} \\
\hline & Domestic & 91 & -.5750697 & .3040346 & \\
\hline & Takeover & 24 & $.5741756^{*}$ & 1385942 & 0.0572 \\
\hline & Greenfield & 92 & $.6921108^{* * *}$ & .0819694 & 0.0001 \\
\hline \multicolumn{6}{|l|}{$\overline{\mathrm{EE}}$} \\
\hline & Domestic & 45 & .5181833 & .3577561 & \\
\hline & Takeover & 13 & $1.988132^{* *}$ & .4150511 & 0.0415 \\
\hline \multicolumn{6}{|l|}{$\overline{\mathrm{HU}}$} \\
\hline & Domestic & 74 & .3601863 & .3733726 & \\
\hline & Takeover & 71 & .645355 & .2614683 & 0.5356 \\
\hline & Greenfield & 117 & $1.338424^{* * *}$ & 1797593 & 0.0094 \\
\hline \multicolumn{6}{|l|}{$\overline{\mathrm{LT}}$} \\
\hline & Domestic & 43 & .0716656 & .4323982 & \\
\hline & Takeover & 26 & .1032947 & .3850739 & 0.9603 \\
\hline \multicolumn{6}{|l|}{$\overline{\mathrm{LV}}$} \\
\hline & Domestic & 121 & .4463572 & .3413123 & \\
\hline & Takeover & 29 & .2353111 & .5803292 & 0.7798 \\
\hline & Greenfield & 11 & -.0749772 & 1.032353 & 0.6579 \\
\hline \multicolumn{6}{|l|}{$\overline{\mathrm{PL}}$} \\
\hline & Domestic & 183 & .9150912 & .1581944 & \\
\hline & Takeover & 70 & .608775 & .1605317 & 0.2656 \\
\hline & Greenfield & 92 & 1.013181 & .212223 & 0.7158 \\
\hline \multicolumn{6}{|l|}{$\mathrm{RO}$} \\
\hline & Domestic & 85 & .1464177 & .4669642 & \\
\hline & Takeover & 22 & $-2.253989^{* *}$ & 1.286483 & 0.0352 \\
\hline & Greenfield & 53 & $1.359179^{*}$ & .2994528 & 0.0592 \\
\hline \multicolumn{6}{|l|}{$\overline{\text { SI }}$} \\
\hline & Domestic & 122 & .9818168 & .0945078 & \\
\hline & Takeover & 8 & $-.2025359^{* * *}$ & 6308978 & 0.0037 \\
\hline & Greenfield & 35 & $.5784625^{*}$ & 1979756 & 0.0518 \\
\hline \multicolumn{6}{|l|}{$\overline{\text { SK }}$} \\
\hline & Domestic & 59 & -.6027444 & .3899188 & \\
\hline & Takeover & 28 & .1523465 & .3145403 & 0.2171 \\
\hline & Greenfield & 56 & $1.444385^{* * *}$ & 1807485 & 0.0000 \\
\hline \multicolumn{6}{|l|}{ All } \\
\hline & Domestic & 930 & 0.4471487 & 0.0943517 & \\
\hline & Takeover & 325 & 0.5124488 & 0.1284826 & 0.7062 \\
\hline & Greenfield & 487 & $1.041758^{* * *}$ & 0.0854614 & 0.000 \\
\hline
\end{tabular}

Source: authors' calculations.

${ }^{1)} \mathrm{p}$-value represents the result of t-test on equality of means between domestic and takeover banks

2) $\mathrm{p}$-value represents the result of t-test on equality of means between domestic and greenfield banks

*** - significant at $1 \%$

** - significant at $5 \%$

* - significant at $10 \%$ 
Table 6. Summary statistics of ROA across countries for foreign banks in the CEEC and their parent banks

\begin{tabular}{|c|c|c|c|c|c|}
\hline & & Obs & Mean & SE & $\mathrm{P}$ \\
\hline \multicolumn{6}{|l|}{ BG } \\
\hline & foreign & 41 & 1.292071 & 0.2728769 & \\
\hline & parent & 41 & $0.5854339^{* *}$ & 0.1718999 & $0.0371^{1)}$ \\
\hline \multicolumn{6}{|l|}{$\overline{\mathrm{CZ}}$} \\
\hline & foreign & 95 & 0.6265304 & 0.0746778 & \\
\hline & parent & 95 & $0.434994^{* *}$ & 0.0418511 & 0.0194 \\
\hline \multicolumn{6}{|l|}{$\overline{\mathrm{EE}}$} \\
\hline & foreign & 13 & 1.988132 & 0.4150511 & \\
\hline & parent & 13 & $0.5709944^{* * *}$ & 0.0504242 & 0.0045 \\
\hline \multicolumn{6}{|l|}{$\overline{\mathrm{HU}}$} \\
\hline & foreign & 138 & 1.019599 & 0.1497359 & \\
\hline & parent & 138 & $0.273358^{* * *}$ & 0.1083372 & 0.0001 \\
\hline \multicolumn{6}{|l|}{$\overline{\mathrm{LT}}$} \\
\hline & foreign & 16 & -0.4189024 & 0.5848849 & \\
\hline & parent & 16 & $0.6338209^{*}$ & 0.1126193 & 0.0938 \\
\hline \multicolumn{6}{|l|}{$\overline{\mathrm{LV}}$} \\
\hline & foreign & 37 & 0.1594823 & 0.5377949 & \\
\hline & parent & 37 & 1.04959 & 0.2513095 & 0.1208 \\
\hline \multicolumn{6}{|l|}{$\overline{\mathrm{PL}}$} \\
\hline & foreign & 134 & 0.8201421 & 0.1245334 & \\
\hline & parent & 134 & $0.397583^{* * *}$ & 0.0378949 & 0.0012 \\
\hline \multicolumn{6}{|l|}{$\overline{\mathrm{RO}}$} \\
\hline & foreign & 57 & -0.209271 & 0.582619 & \\
\hline & parent & 57 & 0.7302416 & 0.1338082 & 0.1109 \\
\hline \multicolumn{6}{|l|}{$\overline{\text { SI }}$} \\
\hline & foreign & 39 & 0.369124 & 0.2162902 & \\
\hline & parent & 39 & 0.3672993 & 0.0386734 & 0.9936 \\
\hline \multicolumn{6}{|l|}{$\overline{\mathrm{SK}}$} \\
\hline & foreign & 78 & 1.073234 & 0.16756 & \\
\hline & parent & 78 & $0.4983467^{* * *}$ & 0.0654325 & 0.0064 \\
\hline
\end{tabular}

All countries

$\begin{array}{lllll}\text { foreign bank } & 648 & 0.7612859 & 0.0788324 & \\ \text { parent bank } & 648 & \mathbf{0 . 4 7 9 0 8 8 7}^{* * *} & 0.0334284 & 0.001\end{array}$

Source: authors' calculations.

${ }^{1)} \mathrm{p}$-value represents the result of t-test on equality of means between parent and foreign banks

*** - significant at $1 \%$

** - significant at $5 \%$

- significant at $10 \%$ 
Table 7. Definition of variables

\begin{tabular}{|c|c|c|}
\hline Symbol & Description & Source of data \\
\hline year_of_takeover ${ }_{i j t}$ & $\begin{array}{l}\text { dummy variable taking the value of } 1 \text { only in year } t \text { if bank } i \text { was } \\
\text { acquired by foreign investor in year } t\end{array}$ & $\begin{array}{l}\text { De Haas \& Lelyveld } \\
+ \text { own research }\end{array}$ \\
\hline$R O A_{i j t}$ & $\begin{array}{l}\text { return on assets of bank } i \text { in host country } j \text { in year } t \text {, calculated as } \\
\text { ratio of profit after taxes to total assets }\end{array}$ & BankScope \\
\hline loan_gr $r_{i j t}$ & real rate of growth of total loans of bank $i$ in country $j$ in year $t$ & BankScope \\
\hline$h \_c a p_{i j t}$ & $\begin{array}{l}\text { capitalization of bank } i \text { in host country } j \text { in year } t \text {, calculated as a } \\
\text { ratio of registered capital to total assets }\end{array}$ & BankScope \\
\hline$h \_i n f_{j t}$ & rate of inflation in host country $j$ in year $t$ & IFS \\
\hline$\overline{R E} E R_{j t}$ & change in real effective exchange rate in host country $j$ in year $t$ & IFS \\
\hline$h \_g d p_{j t}$ & real rate of growth of GDP in host country $j$ in year $t$ & $I F S$ \\
\hline$h_{-}$irate $_{j t}$ & real short-term interest rate in host country $j$ in year $t$ & IFS \\
\hline credit $_{j t}$ & $\begin{array}{l}\text { ratio of credit to the private sector to GDP in host country } j \text { in year } \\
t\end{array}$ & $B S C E E$ \\
\hline$E B R D_{j t}$ & EBRD index of banking sector reforms in host country $j$ in year $t$ & $\begin{array}{r}\text { EBRD transition } \\
\text { report }\end{array}$ \\
\hline stock $_{j t}$ & $\begin{array}{l}\text { ratio of stock market capitalization to GDP in host country } j \text { in } \\
\text { year } t\end{array}$ & $\begin{array}{r}\text { National stock } \\
\text { exchanges }\end{array}$ \\
\hline share $_{j t}$ & $\begin{array}{l}\text { share of assets of bank } i \text { in host country } j \text { in year } t \text { in total assets of } \\
\text { banking sector in host country } j \text { in year } t\end{array}$ & BankScope \\
\hline$H H I_{j t}$ & $\begin{array}{l}\text { Herfindahl index in host country } j \text { in year } t \text {, calculated as the sum } \\
\text { of squared shares of assets }\end{array}$ & BankScope \\
\hline foreign $_{i j t}$ & $\begin{array}{l}\text { dummy variable taking the value of } 1 \text { if bank } i \text { in host country } j \text { in } \\
\text { year } t \text { was owned by a foreign institution }\end{array}$ & $\begin{array}{l}\text { De Haas \& Lelyveld } \\
+ \text { own research }\end{array}$ \\
\hline takeover $_{i j t}$ & $\begin{array}{l}\text { dummy variable taking the value of } 1 \text { in year } t \text { and consecutive } \\
\text { years if bank } i \text { was acquired by foreign investor in year } t\end{array}$ & $\begin{array}{r}\text { De Haas \& Lelyveld } \\
+ \text { own research }\end{array}$ \\
\hline greenfield $_{i j t}$ & $\begin{array}{l}\text { dummy variable taking the value of } 1 \text { in year } t \text { and consecutive } \\
\text { years if bank } i \text { was established by foreign investor in year } t\end{array}$ & $\begin{array}{r}\text { De Haas \& Lelyveld } \\
+ \text { own research }\end{array}$ \\
\hline crisis $_{j t}$ & $\begin{array}{l}\text { dummy variable taking the value of } 1 \text { if country experiences a } \\
\text { banking crisis or recapitalization of banks }\end{array}$ & Caprio \& Klingebiel \\
\hline$p_{-} N I M_{i j t}$ & $\begin{array}{l}\text { net interest margin of parent bank in year } t \text {, calculated as a ratio of } \\
\text { the difference between interest income and interest expenses to } \\
\text { total assets }\end{array}$ & BankScope \\
\hline$p_{-} c a p_{i j t}$ & $\begin{array}{l}\text { capitalization of parent bank of the bank } i \text { in country } j \text { in year } t \\
\text { calculated as a ratio of registered capital to total assets }\end{array}$ & BankScope \\
\hline$p \_g d p_{i j t}$ & $\begin{array}{l}\text { real rate of growth of GDP in home country of the bank } i \text { in } \\
\text { country } j \text { in the year } t\end{array}$ & IFS \\
\hline p_irate ijt $_{1}$ & $\begin{array}{l}\text { real short-term interest rate in home country of bank } i \text { in country } j \\
\text { in the year } t\end{array}$ & IFS \\
\hline$\eta_{i}$ & dummy variable taking the value of 1 for each bank $i$ & \\
\hline$\mu_{j}$ & dummy variable taking the value of 1 for each host country $j$ & \\
\hline $\begin{array}{l}\gamma_{t} \\
\text { home }_{i j t}\end{array}$ & $\begin{array}{l}\text { dummy variable taking the value of } 1 \text { for each time period } t \\
\text { a vector of dummy variables taking the value of } 1 \text { if parent banks } \\
\text { comes from country home, which includes Austria, Belgium, } \\
\text { Denmark, Finland, Germany, Greece, Hungary, Japan, Latvia, } \\
\text { Italy, Netherlands, Portugal, Russia, Sweden, the UK, and the US }\end{array}$ & $\begin{array}{r}\text { BankScope }+ \text { own } \\
\text { research }\end{array}$ \\
\hline
\end{tabular}


Table 8. Estimation results of the logit model.

\begin{tabular}{|c|c|c|c|}
\hline year_of_takeover & Year of takeover & $\begin{array}{r}\text { One year before } \\
\text { takeover }\end{array}$ & $\begin{array}{r}\text { Two years } \\
\text { before takeover }\end{array}$ \\
\hline & (1) & (2) & (3) \\
\hline \multirow[t]{2}{*}{ ROA } & $-0.096^{* *}$ & -0.069 & $0.111^{*}$ \\
\hline & $(0.050)$ & $(0.061)$ & $(0.058)$ \\
\hline \multirow[t]{2}{*}{ loan growth } & -0.001 & $0.0003^{* * *}$ & $-0.007^{* *}$ \\
\hline & $(0.002)$ & $(0.000)$ & (0.003) \\
\hline \multirow[t]{2}{*}{ host inflation } & $-0.026^{* *}$ & -0.007 & $-0.008^{* *}$ \\
\hline & $(0.011)$ & $(0.013)$ & $(0.004)$ \\
\hline \multirow[t]{2}{*}{ REER } & 0.032 & 0.009 & $-0.08^{* *}$ \\
\hline & $(0.02)$ & $(0.032)$ & $(0.036)$ \\
\hline \multirow[t]{2}{*}{ credit private } & $-0.04^{*}$ & $-0.027^{*}$ & $-0.037^{*}$ \\
\hline & $(0.021)$ & $(0.015)$ & (0.019) \\
\hline \multirow[t]{2}{*}{ stock market } & -0.007 & $0.046^{* *}$ & 0.032 \\
\hline & $(0.019)$ & $(0.021)$ & $(0.028)$ \\
\hline \multirow[t]{2}{*}{ host GDP } & $-0.127^{*}$ & 0.018 & $-0.144^{*}$ \\
\hline & $(0.074)$ & $(0.05)$ & $(0.088)$ \\
\hline \multirow[t]{2}{*}{ host interest rate } & -0.0002 & -0.028 & $-0.076^{* *}$ \\
\hline & $(0.024)$ & $(0.027)$ & $(0.037)$ \\
\hline \multirow[t]{2}{*}{ EBRD } & -0.039 & $-0.87^{*}$ & -0.788 \\
\hline & $(0.597)$ & $(0.468)$ & $(0.848)$ \\
\hline \multirow[t]{2}{*}{ HHI } & 0.974 & -1.298 & -3.685 \\
\hline & $(1.424)$ & $(1.776)$ & (3.574) \\
\hline \multirow[t]{2}{*}{ crisis } & -1.52 & 0.058 & 0.789 \\
\hline & (1.273) & (.529) & (0.679) \\
\hline \multirow[t]{2}{*}{ share } & $0.026^{* * *}$ & $0.03^{* * *}$ & $0.021^{*}$ \\
\hline & $(0.009)$ & $(0.009)$ & $(0.013)$ \\
\hline \multirow[t]{2}{*}{ cons } & -1.213 & 0.099 & 1.627 \\
\hline & $(1.651)$ & $(1.42)$ & $(2.548)$ \\
\hline Number of obs. & 912 & 714 & 517 \\
\hline Log likelihood & -197.03 & -170.71 & -117.56 \\
\hline Pseudo R2 & 0.064 & 0.058 & 0.082 \\
\hline
\end{tabular}

Source: authors' calculations.

Dependent variable is takeover which takes the value of 1 if a bank was acquired by a foreign owner, and 0 otherwise. Greenfield banks are excluded from estimation. 
Table 9. Panel estimation of determinants on banks’ ROA with individual home country macro variables

\begin{tabular}{|c|c|c|c|c|c|c|}
\hline & All banks & All banks & Domestic & Foreign & Greenfield & Takeover \\
\hline & $(1)$ & (2) & (3) & (4) & (5) & (6) \\
\hline \multirow[t]{2}{*}{ loan growth } & $-0.00004 * * *$ & $-0.00004^{* * *}$ & $-0.0003^{* * *}$ & $-0.00003^{* * *}$ & $-0.00003^{* * *}$ & 0.0004 \\
\hline & 0.000005 & 0.000005 & 0.0001 & 0.000003 & 0.000003 & 0.0009 \\
\hline \multirow[t]{2}{*}{ capital } & $0.096 * * *$ & $0.096 * * *$ & $0.122 * * *$ & 0.041* & $0.047 * *$ & 0.010 \\
\hline & 0.022 & 0.022 & 0.035 & 0.023 & 0.019 & 0.071 \\
\hline \multirow[t]{2}{*}{ host inflation } & $0.005 * *$ & $0.004 * *$ & 0.002 & $0.007 * * *$ & $0.007 * * *$ & -0.127 \\
\hline & 0.002 & 0.002 & 0.002 & 0.001 & 0.001 & 0.160 \\
\hline \multirow[t]{2}{*}{ REER } & $0.028 * * *$ & $0.028 * * *$ & $0.051 * * *$ & $0.021 * *$ & -0.001 & $0.079 * *$ \\
\hline & 0.010 & 0.010 & 0.020 & 0.011 & 0.011 & 0.034 \\
\hline \multirow[t]{2}{*}{ host GDP } & $0.078 * *$ & $0.077 * *$ & $0.121 * * *$ & -0.037 & $-0.091 *$ & 0.202 \\
\hline & 0.030 & 0.030 & 0.045 & 0.051 & 0.047 & 0.138 \\
\hline \multirow[t]{2}{*}{ host interest rate } & 0.002 & 0.001 & 0.0001 & 0.014 & 0.015 & -0.023 \\
\hline & 0.014 & 0.014 & 0.020 & 0.016 & 0.014 & 0.083 \\
\hline \multirow[t]{2}{*}{ credit private } & 0.021* & $0.021 *$ & -0.001 & 0.023* & 0.011 & 0.010 \\
\hline & 0.011 & 0.011 & 0.020 & 0.013 & 0.011 & 0.028 \\
\hline \multirow[t]{2}{*}{ EBRD } & $1.531 * * *$ & $1.545 * * *$ & $1.784 * * *$ & $1.094^{*}$ & 0.329 & $3.202 * *$ \\
\hline & 0.439 & 0.439 & 0.674 & 0.574 & 0.415 & 1.533 \\
\hline \multirow[t]{2}{*}{ stock market } & $-0.045 * * *$ & $-0.046 * * *$ & $-0.062 * * *$ & $-0.039 * *$ & $-0.031 * *$ & $-0.094^{* *}$ \\
\hline & 0.013 & 0.013 & 0.023 & 0.016 & 0.016 & 0.042 \\
\hline \multirow[t]{2}{*}{ share } & -0.019 & -0.019 & -0.027 & $-0.157 *$ & -0.017 & -0.232 \\
\hline & 0.029 & 0.029 & 0.040 & 0.088 & 0.068 & 0.192 \\
\hline \multirow[t]{2}{*}{ HHI } & $6.352 * * *$ & $6.379 * * *$ & $7.878 * * *$ & 3.184 & -0.949 & 19.973 \\
\hline & 2.382 & 2.384 & 3.022 & 4.270 & 3.067 & 14.105 \\
\hline \multirow[t]{2}{*}{ foreign } & 0.263 & & & & & \\
\hline & 0.255 & & & & & \\
\hline \multirow[t]{2}{*}{ greenfield } & & 3.296 & & & & \\
\hline & & 2.065 & & & & \\
\hline \multirow[t]{2}{*}{ takeover } & & 0.254 & & & & \\
\hline & & 0.255 & & & & \\
\hline \multirow[t]{2}{*}{ parent NIM } & & & & $-0.413^{*}$ & $-0.363^{* * *}$ & -0.674 \\
\hline & & & & 0.237 & 0.141 & 0.567 \\
\hline \multirow[t]{2}{*}{ parent capital } & & & & -0.028 & 0.081 & -0.104 \\
\hline & & & & 0.083 & 0.060 & 0.140 \\
\hline \multirow[t]{2}{*}{ parent GDP } & & & & 0.026 & 0.052 & -0.037 \\
\hline & & & & 0.054 & 0.072 & 0.120 \\
\hline \multirow[t]{2}{*}{ parent int. rate } & & & & -0.007 & -0.005 & 0.010 \\
\hline & & & & 0.026 & 0.055 & 0.029 \\
\hline \multirow[t]{2}{*}{ crisis } & 0.614 & 0.581 & 0.989* & 0.509 & & \\
\hline & 0.418 & 0.417 & 0.514 & 0.596 & & \\
\hline \multirow[t]{2}{*}{ crisis*takeover } & 0.192 & 0.238 & & & & 1.910 \\
\hline & 0.507 & 0.505 & & & & 1.359 \\
\hline \multirow[t]{2}{*}{ crisis*greenfield } & 0.106 & 0.267 & & -0.604 & 0.035 & \\
\hline & 0.450 & 0.450 & & 0.641 & 0.246 & \\
\hline Observations & 1270 & 1270 & 688 & 582 & 358 & 224 \\
\hline $\mathrm{R}^{2}$ & 0.16 & 0.15 & 0.16 & 0.27 & 0.37 & 0.42 \\
\hline Hausman test & 61.36 & 66.88 & 64.14 & 43.04 & 52.64 & 39.14 \\
\hline
\end{tabular}

Source: authors' calculations. 
Table 10. Panel estimation of determinants on banks’ ROA with EU macro variables and with parent ROA

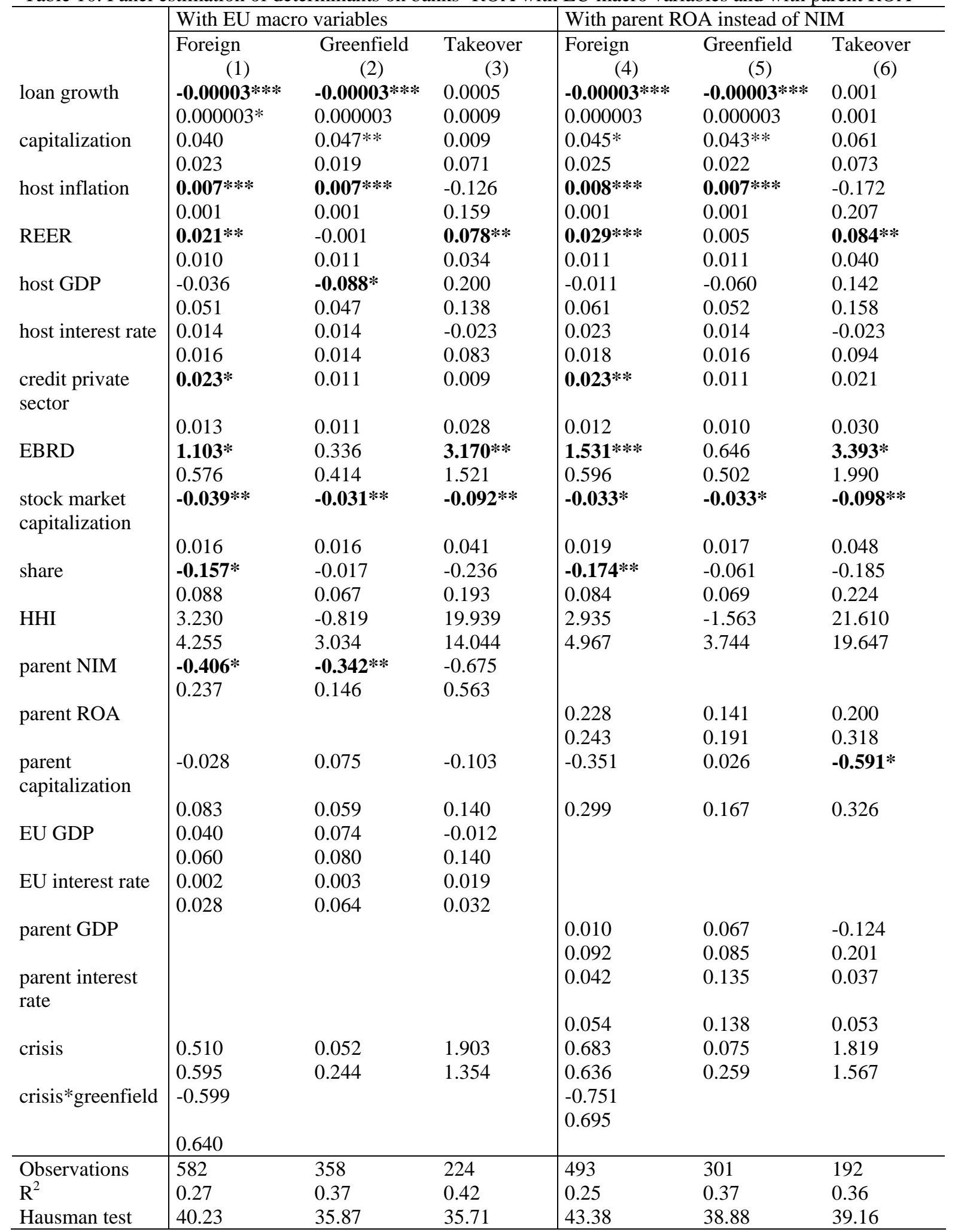

Source: authors' calculations. 
Copyright ( 22006 @ the author(s). Discussion papers are in draft form. This discussion paper is distributed for purposes of comment and discussion only. It may not be reproduced without permission of the copyright holder. Copies of working papers are available from the author. 